\title{
Melatonin mediates vasodilation through both direct and indirect activation of $\mathrm{BK}_{\mathrm{Ca}_{\mathrm{a}}}$ channels
}

\author{
T Zhao, H Zhang, C Jin, F Qiu, Y Wu and L Shi \\ Department of Exercise Physiology, Beijing Sport University, Beijing, China
}

Correspondence should be addressed to L Shi

Email

I_j_shi72@163.com

\begin{abstract}
Melatonin, synthesized primarily by the pineal gland, is a neuroendocrine hormone with high membrane permeability. The vascular effects of melatonin, including vasoconstriction and vasodilation, have been demonstrated in numerous studies. However, the mechanisms underlying these effects are not fully understood. Largeconductance $\mathrm{Ca}^{2+}$-activated $\mathrm{K}+\left(\mathrm{BK}_{\mathrm{Ca}}\right)$ channels are expressed broadly on smooth muscle cells and play an important role in vascular tone regulation. This study explored the mechanisms of myocyte $\mathrm{BK}_{\mathrm{Ca}}$ channels and endothelial factors underlying the action of melatonin on the mesenteric arteries (MAs). Vascular contractility and patch-clamp studies were performed on myocytes of MAs from Wistar rats. Melatonin induced significant vasodilation on MAs. In the presence of $N^{\omega}$-nitro-L-arginine methyl ester (L-NAME), a potent endothelial oxide synthase (eNOS) inhibitor, melatonin elicited concentration-dependent relaxation, with lowered $\mathrm{pIC}_{50}$. The effect of melatonin was significantly attenuated in the presence of $\mathrm{BK}_{\mathrm{Ca}}$ channel blocker iberiotoxin or MT1/ MT2 receptor antagonist luzindole in both (+) L-NAME and (-) L-NAME groups. In the (+) L-NAME group, iberiotoxin caused a parallel rightward shift of the melatonin concentration-relaxation curve, with $\mathrm{plC}_{50}$ lower than that of luzindole. Both inside-out and cell-attached patch-clamp recordings showed that melatonin significantly increased the open probability, mean open time and voltage sensitivity of $\mathrm{BK}_{\mathrm{Ca}}$ channels. In a cell-attached patch-clamp configuration, the melatonin-induced enhancement of $\mathrm{BK}_{\mathrm{Ca}}$ channel activity was significantly suppressed by luzindole. These findings indicate that in addition to the activation of eNOS, melatonin-induced vasorelaxation of MAs is partially attributable to its direct (passing through the cell membrane) and indirect (via MT1/MT2 receptors) activation of the $\mathrm{BK}_{\mathrm{Ca}}$ channels on mesenteric arterial myocytes.
\end{abstract}

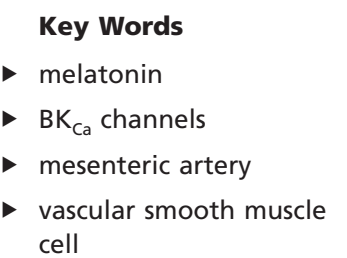

Journal of Molecular Endocrinology (2017) 59, 219-233

\section{Introduction}

Melatonin (N-acetyl-5-methoxytryptamine) is the primary hormone of the pineal gland, mainly secreted at night (Saarela \& Reiter 1994). Increasing evidence indicates that melatonin plays an important role in regulating cardiovascular homeostasis as well as in the formation and organization of biorhythms (Cook et al. 2011, Grossini et al. 2011, Pandi-Perumal et al. 2016, Sun et al. 2016, Tang et al. 2016, Tordjman et al. 2017).
() 2017 Society for Endocrinology Printed in Great Britain 
By regulating blood vessel diameter, melatonin affects arterial blood pressure and local blood flow to organs and tissues (Cook et al. 2011, Pandi-Perumal et al. 2008).

Melatonin exerts many of its physiological actions through interaction with specific melatonin receptors that are present in mammalian tissues (Pandi-Perumal et al. 2008, Zlotos et al. 2014). Three high-affinity melatonin receptor subtypes - MT1, MT2, and MT3 receptors have been identified and cloned (Nosjean et al. 2000, Dubocovich et al. 2003). Melatonin predominantly acts via two G-protein-coupled receptors: MT1 and MT2 (Pandi-Perumal et al. 2008). The activation of melatonin receptors on endothelial and vascular smooth muscle cells and antioxidant properties of melatonin could be responsible for the melatonin effects on vascular tone (Paulis \& Simko 2007). The effects of melatonin on vascular function are complex; melatonin receptor activation causes vasoconstriction in some vasculatures and vasodilation in others. For instance, melatonin has been found to elicit vasoconstriction in certain arteries (Evans et al. 1992, Geary et al. 1997, Ting et al. 1997, Viswanathan et al. 1997), such as coronary vessels, the renal vascular bed (Yang et al. 2001, Cook et al. 2011, Tunstall et al. 2011) and cerebral arteries (Geary et al. 1997, 1998), whereas it induces vasodilation in others (Satake et al. 1991, Weekley 1991, Doolen et al. 1998), such as aorta, pulmonary and umbilical vascular bed, and mesenteric arteries (MAs) (Weekley et al. 1993, Girouard et al. 2001, Thakor et al. 2010). These opposite effects may due to melatonin's binding to 2 different receptors, which are differently distributed on different vascular beds (Doolen et al. 1998). The activation of MT1 receptors has been widely associated with cAMP decrease and phosphatidylinositol-4,5-bisphosphate hydrolysis, which would lead to the inhibition of vasodilation or vasoconstriction (Paulis \& Simko 2007). The activation of MT2 receptors on endothelial cells (ECs) may involve an increased nitric oxide (NO) production and an endothelium-dependent vasodilation (Anwar et al. 2001, Paulis \& Simko 2007, Reiter et al. 2009).

Both endothelium-dependent and non-endotheliumdependent pathways are involved in melatonin's effects on blood vessels, which mainly occur following activation of MT1 and/or MT2 receptors (Paulis \& Simko 2007, Hung et al. 2013). In addition to these well-established mechanisms, MT1 receptors have also been reported to couple to large-conductance $\mathrm{Ca}^{2+}$-activated $\mathrm{K}^{+}\left(\mathrm{BK}_{\mathrm{Ca}}\right)$ channels $(13,18)$ and to $G$ protein-activated inward rectifier $\mathrm{K}^{+}$channels (GIRK Kir 3) (Jiang et al. 1995), which indicates that $\mathrm{K}^{+}$channels on vascular myocytes are potential targets of melatonin. $\mathrm{BK}_{\mathrm{Ca}}$ channels, activated by both membrane depolarization and intracellular calcium, are broadly expressed on smooth muscle cells (SMCs) and play a critical role in vascular tone regulation (Nelson \& Quayle 1995, Ledoux et al. 2006, Ko et al. 2008). There is indirect evidence for the inhibition of $\mathrm{BK}_{\mathrm{Ca}}$ channels by melatonin in rat cerebral arteries (Geary et al. 1997, 1998).

Previous studies have demonstrated that melatonin has high membrane permeability and displays high lipophilicity (Yu et al. 2016). Melatonin can enter and leave cells in seconds; the literature therefore suggests that melatonin is secreted by simple diffusion across the pinealocyte plasma membrane (Simonneaux \& Ribelayga 2003, Yu et al. 2016). Given this background, we wondered whether these small molecules could pass through the cell membrane and act on $\mathrm{BK}_{\mathrm{Ca}}$ channels directly. To date, no studies have investigated this hypothesis.

In the rat, the mesenteric circulation receives approximately one-fifth of the cardiac output; thus, regulation of this bed makes a significant contribution to the regulation of systemic blood pressure (Nichols et al. 1985). Previous studies have shown that melatonin induces vasodilation in the MAs (Girouard et al. 2001). Although endothelium-independent and cycle AMPdependent mechanisms have been suggested, the precise mechanisms by which melatonin affects the vascular tone of the MAs have not been fully determined. Therefore, this study was designed to determine (1) whether melatonin activates $\mathrm{BK}_{\mathrm{Ca}}$ channels on MA SMCs; (2) whether both direct and indirect activation of $\mathrm{BK}_{\mathrm{Ca}}$ channels are involved in melatonin-induced vasorelaxation of MAs. The information obtained will expand the knowledge of melatonin's effect on the peripheral resistance arteries and enhance understanding of the potential effects of melatonin on blood pressure regulation in humans.

\section{Materials and methods}

\section{Animals}

Eight-week-old male Wistar rats weighing 180-220g were used in these experiments. The animals were housed under controlled conditions with a $12 \mathrm{~h}$ light-darkness cycle and ambient temperature of $24^{\circ} \mathrm{C}$, with food and water available ad libitum. All experimental procedures and protocols conformed to the recommended guidelines on the care and use of laboratory animals issued by the Chinese Council on Animal Research. The study was approved by the ethical committee of Beijing Sport University.

Published by Bioscientifica Ltd. 


\section{Immunofluorescence}

For immunofluorescence staining, MA sections were fixed with 4\% paraformaldehyde in PBS for an hour at room temperature and then permeabilized by $0.2 \%$ Triton X-100 for $15 \mathrm{~min}$. After extensive washing with PBS, the tissue sections were blocked for non-specific antibody binding 60 min with 5\% BSA, then incubated in a rabbit polyclonal antibody specific for Anti-Melatonin Receptor Type 1 (Alomone Labs, Jerusalem, Israel; 1:200) or AntiMelatonin Receptor Type 2 overnight at $4^{\circ} \mathrm{C}$. The second Alexa Fluor 488 Goat Anti-Rabbit IgG antibody (Molecular Probes, 1:1000) was used for $1 \mathrm{~h}$ next day after washing. The fluorescence images were captured using a TCS-SP5 confocal laser scanning microscope (Leica). Image analysis software was performed in ImageJ (NIH, version1.46r).

\section{Assessment of vascular function}

The animals were euthanized with sodium pentobarbital $(100 \mathrm{mg} / \mathrm{kg}$, i.p.). The MA and its branches were removed and placed in cold Krebs solution with a composition of $131.5 \mathrm{mM} \mathrm{NaCl}, 5 \mathrm{mM} \mathrm{KCl}, 1.2 \mathrm{mM} \mathrm{NaH} \mathrm{PO}_{4}, 1.2 \mathrm{mM}$ $\mathrm{MgCl}_{2}, \quad 2.5 \mathrm{mM} \mathrm{CaCl}, \quad 11.2 \mathrm{mM}$ glucose, $13.5 \mathrm{mM}$ $\mathrm{NaHCO}_{3}, 0.025 \mathrm{mM}$ EDTA $\left(37^{\circ} \mathrm{C}, \mathrm{pH} 7.4\right)$, and aerated with $95 \% \mathrm{O}_{2}$ and $5 \% \mathrm{CO}_{2}$. Short segments of $\mathrm{A} 3$ were used for contractile studies performed with a multi myograph system (620M, DMT, Denmark) per the procedures in previous studies (Shi et al. 2015).

For all vessels, we evaluated the contractile response for tension by measuring the maximum peak height and expressing it as the percentage of maximal tension achieved to $60 \mathrm{mM} \mathrm{K} \mathrm{K}^{+}\left(K_{\max }\right)$, and calculated $\mathrm{pIC}_{50}$ $\left(-\log \mathrm{IC}_{50}\right.$, the negative logarithm of the half-maximal inhibitory concentration, a measure of the effectiveness of a substance in inhibiting a specific biological or biochemical function). To examine the effect of melatonin on vascular tone, tissues were first contracted with $10^{-5} \mathrm{M}$ norepinephrine (NE). Then, responses to the cumulative addition of melatonin $\left(10^{-7}-10^{-3} \mathrm{M}\right)$ were tested. In some experiments, non-selective nitric oxide synthase (NOS) inhibitor $N^{\omega}$-nitro-L-arginine methyl ester (L-NAME, $100 \mu \mathrm{M}$ ) was added after $K_{\max }$ measurement.

\section{Cell isolation}

MAs were removed, cleaned of fat and connective tissue, cut into tissue pieces $(0.5-1 \mathrm{~mm}$ in both length and width) and placed in digestion buffer $\left(\mathrm{Ca}^{2+}\right.$-free ice-cold physiological salt solution I (PSS I)) containing $137 \mathrm{mM}$
$\mathrm{NaCl}, 5.6 \mathrm{mM} \mathrm{KCl}, 1 \mathrm{mM} \mathrm{MgCl}, 10 \mathrm{mM}$ HEPES and $10 \mathrm{mM}$ glucose (adjusted to 7.4 with $\mathrm{NaOH}$ ). Dissected segments were incubated for $30 \mathrm{~min}$ at $37^{\circ} \mathrm{C}$ in digestion buffer supplemented with papain $(0.3 \mathrm{mg} / \mathrm{mL}$, Worthington Biochemical, USA) and dithiothreitol $(1 \mathrm{mg} / \mathrm{mL}$, SigmaAldrich), followed by a second incubation $(20 \mathrm{~min}$ at $37^{\circ} \mathrm{C}$ ) in digestion buffer supplemented with collagenases Type F $(1.5 \mathrm{mg} / \mathrm{mL}$, Sigma) and Type $1-\mathrm{S}(1 \mathrm{mg} / \mathrm{mL}$, SigmaAldrich). Tissues were then washed 3-4 times with PSS II containing $137 \mathrm{mM} \mathrm{NaCl}, 5.6 \mathrm{mM} \mathrm{KCl}, 1 \mathrm{mM} \mathrm{MgCl}$, $10 \mathrm{mM}$ HEPES, $10 \mathrm{mM}$ glucose, $0.42 \mathrm{mM} \mathrm{Na}_{2} \mathrm{HPO}_{4}$, and $0.44 \mathrm{mM} \mathrm{NaH} \mathrm{PO}_{4}\left(99.9 \% \mathrm{O}_{2}\right.$ for $40 \mathrm{~min}$, adjusted to 7.3-7.4 with $\mathrm{NaOH}$ ), and triturated gently using a firepolished pipette to create a cell suspension.

\section{Electrophysiological recording techniques}

Standard patch-clamp recording techniques were used to measure currents in the cell-attached or inside-out patch configuration (Hamill et al. 1981). Currents were amplified using an Axon700B amplifier, sampled at $10 \mathrm{KHz}$ and filtered at $2 \mathrm{KHz}$ with an 8 -pole Bessel filter.

Conventional whole-cell recording Whole-cell $\mathrm{K}^{+}$currents were measured with conventional voltageclamp configuration. The cell bath solution comprised the following (mM): $134 \mathrm{NaCl}, 6 \mathrm{KCl}, 1 \mathrm{MgCl}_{2}, 1.8 \mathrm{CaCl}_{2}$, 10 glucose and 10 HEPES (pH 7.4 with $\mathrm{KOH}$ ). The pipette solution contained the following $(\mathrm{mM}): 110 \mathrm{~K}-\mathrm{Asp}, 30 \mathrm{KCl}$, 1 EGTA, $3 \mathrm{Na}_{2} \mathrm{ATP}, 0.85 \mathrm{CaCl}_{2}, 10$ glucose and 10 HEPES (pH 7.2 with $\mathrm{KOH}$ ). Outward $\mathrm{K}^{+}$currents were elicited by a series of $400 \mathrm{~ms}$ depolarizing voltage steps. To measure current $(I)$-voltage $(V)$ relationships, cells were held at $-60 \mathrm{mV}$ and then stepped to test potentials from -60 to $+80 \mathrm{mV}$ in $10 \mathrm{mV}$ increments for $400 \mathrm{~ms}$ at each potential. To assess $\mathrm{BK}_{\mathrm{Ca}}$ and voltage-dependent potassium channel $\left(\mathrm{K}_{\mathrm{V}}\right)$ current amplitudes, outward $\mathrm{K}^{+}$currents were elicited in the absence and presence of $100 \mathrm{nM}$ iberiotoxin (IbTX) or $3 \mathrm{mM} 4$-aminopyridine (4-AP).

Single-channel recording The pipette resistance ranged from 10 to $15 \mathrm{M} \Omega$ in the cell-attached and insideout patch experiments. Recording pipette electrodes were fabricated from disposable micro-pipettes (BF150-86-10, Sutter Instrument, USA; ID: $0.86 \mathrm{~mm}$, OD: $1.50 \mathrm{~mm}$ ) in 2 stages on a vertical electrode puller (PC10, Narishige, Japan) to give resistances of $10-15 \mathrm{M} \Omega$ when filled with solution. The bath solution (PSS) and the pipette solution were identical and contained $45 \mathrm{mM} \mathrm{KCl}, 100 \mathrm{mM} \mathrm{K}$-Asp,

Published by Bioscientifica Ltd. 
$1 \mathrm{mM}$ EGTA, $10 \mathrm{mM}$ HEPES and $5 \mathrm{mM}$ glucose, adjusted to $\mathrm{pH} 7.4$ with $\mathrm{KOH}$. Pipettes were filled with $100 \mathrm{mM}$ $\mathrm{KCl}, 45 \mathrm{mM}$ K-Asp, $1 \mathrm{mM}$ EGTA, $10 \mathrm{mM}$ HEPES and $5 \mathrm{mM}$ glucose, adjusted to $\mathrm{pH} 7.4$ with $\mathrm{KOH}$. As previously described (Shi et al. 2013), $\mathrm{Ca}^{2+}\left(\mathrm{CaCl}_{2}\right)$ was added to achieve the desired level of free $\mathrm{Ca}^{2+}$ (determined using WinMAXC software; Chris Patton, Stanford University).

For single $\mathrm{BK}_{\mathrm{Ca}}$ channel recording, as an index of channel steady-state activity, we used the product of the number of channels in the patch $(N)$ and the channel open probability (Po). The number of $\mathrm{BK}_{\mathrm{Ca}}$ was estimated from the maximum observed current level at relatively high voltage and/or bath $\mathrm{Ca}^{2+}$ concentration. The Po, amplitude and kinetic characteristics of the channels were analyzed with pCLAMP software (Clampfit 10.2); only recordings with stable Po values for a minimum of $2 \mathrm{~min}$ were analyzed.

Voltage-dependent behavior of the channel Po was modeled with the Boltzmann function:

$$
P_{0}=1 /\left\{1+\exp \left[-\mathrm{ZF} / \mathrm{RT}\left(V-V_{1 / 2}\right)\right]\right\}
$$

where $V_{1 / 2}$ is the membrane potential for the half-maximal channel activation.

The $\mathrm{Ca}^{2+}$-dependent activation was fitted with the Hill equation:

$$
P_{0}=\left[\mathrm{Ca}^{2+}\right]_{i} \eta^{H} /\left(K_{d} \eta^{H}+\left[\mathrm{Ca}^{2+}\right]_{\mathrm{i}} \eta^{H}\right)
$$

where $\eta^{\mathrm{H}}$ is the Hill coefficient, and $K_{d}$ is the dissociation constant.

\section{Chemicals and statistics}

All chemicals were purchased from Sigma-Aldrich unless otherwise stated. Statistical analysis was conducted using either one-way analysis of variance (ANOVA) followed by a Tukey's post hoc test for multiple comparisons or a paired Student's $t$-test; values of $P<0.05$ were considered significant. Data are expressed as mean \pm S.D.; $n$ refers to the number of animals studied. Concentration-response curves were analyzed by computer-assisted nonlinear regression to fit the data using GraphPad Prism (GraphPad Software) to obtain $-\operatorname{logIC}_{50}\left(\mathrm{pIC}_{50}\right)$. Melatonin is first dissolved in dimethyl sulfoxide (DMSO). The final concentration of DMSO was less than $0.1 \%$ that had no effects on currents.

\section{Results}

\section{MT1 and MT2 receptor expression in MAs}

Using immunofluorescence and confocal imaging, we examined the distribution of MT1 and MT2 receptors in
MAs. As shown in Fig. 1A, MT1 and MT2 receptors were detected in both endothelium and VSMCs.

\section{Melatonin-induced vasodilation of MAs}

In each MA ring, a high dose of potassium $(60 \mathrm{mM} \mathrm{KCl})$ was first applied to induce the maximal contraction $(100 \%$ $\left.K_{\max }\right)$. Then, 2 sets of experiments with or without L-NAME $(100 \mu \mathrm{M})$ treatment were conducted in separate artery rings. In the absence of L-NAME (Fig. 1B), norepinephrine $\left(\mathrm{NE}, 10^{-5} \mathrm{M}\right.$ ) induced a significant increase of vascular tone, $160.5 \pm 7.6 \% K_{\max }(n=8)$. At the plateau of NE-induced contraction, melatonin $\left(10^{-7}-10^{-3} \mathrm{M}\right)$ was administered in half-log increments. As shown in Fig. 1B and E, melatonin induced dose-dependent vascular relaxation in MAs. Here, $10^{-5} \mathrm{M}$ NE-induced maximal tension increase was treated as $100 \%$. The $\mathrm{pIC}_{50}$ value (negative logarithm of the molar concentration required to block the NE-induced contraction by $50 \%$ ) in the melatonin-treated group was $4.75 \pm 0.11(n=8$, Fig. 1E). In the presence of L-NAME (Fig. 1C), the maximal NE-induced force was $182.8 \pm 9.2 \%$ $K_{\max }(n=8)$, which was higher than that in the absence of L-NAME $\left(160.5 \pm 7.6 \% K_{\max }, P<0.01\right)$. Notably, L-NAME by itself had no effect on basal tone, but it did significantly increase contractile responses to NE. In the presence of L-NAME (Fig. 1F), melatonin also elicited a concentrationdependent relaxation with $\mathrm{pIC}_{50}=3.93 \pm 0.12(n=8$, $P<0.01$, vs (-) L-NAME). These results suggest that melatonin-induced vasorelaxation is partially due to the activation of eNOS.

In order to examine the role of the $\mathrm{BK}_{\mathrm{Ca}}$ channel in melatonin-induced vascular relaxation, iberiotoxin (IbTX, a specific $\mathrm{BK}_{\mathrm{Ca}}$ channel blocker, $10^{-8} \mathrm{M}$ ) was added to the bath to incubate the MA rings. In both L-NAME-treated and untreated groups, $10^{-8} \mathrm{M}$ IbTX did not change the resting tension (Fig. 1C). However, after 2-min incubation with IbTX, a parallel rightward shift of the melatonin concentration-relaxation curve was detected in both L-NAME-treated and untreated groups, compared to those without IbTX incubation (Fig. 1B, C, E and F). The $\mathrm{pIC}_{50}$ was $4.11 \pm 0.09$ in the $(-) \mathrm{L}-\mathrm{NAME}+\mathrm{IbTX}$ group, which was lower than that in the group without IbTX treatment $\left((-)\right.$ L-NAME: $\mathrm{pIC}_{50}=4.75 \pm 0.11$, both $\left.n=8, P<0.01\right)$. The $\mathrm{pIC}_{50}$ was $2.74 \pm 0.13$ in the $(+) \mathrm{L}-\mathrm{NAME}+\mathrm{IbTX}$ group, which was also lower than that in the group without IbTX treatment $\left((+)\right.$ L-NAME: $\mathrm{pIC}_{50}=3.93 \pm 0.12, P<0.01, n=8$ in each group). It should be noted that following IbTX incubation, the melatonin concentration-relaxation curve was markedly rightward-shifted in the $(+)$ L-NAME group $\left(\mathrm{pIC}_{50}=2.74 \pm 0.13\right)$ compared to that of the

Published by Bioscientifica Ltd. 


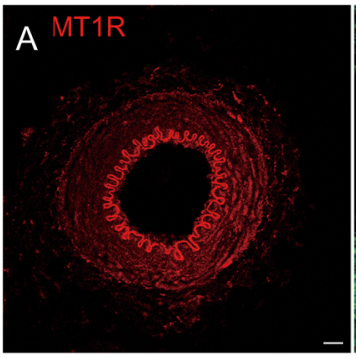

B

a

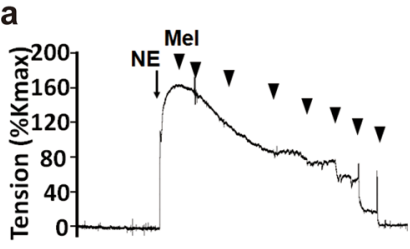

b
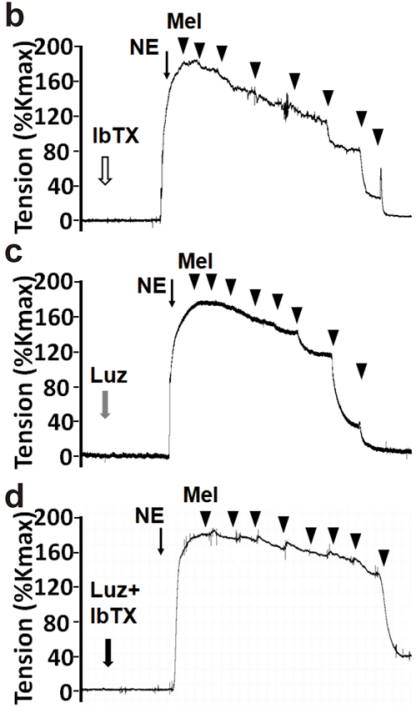

E

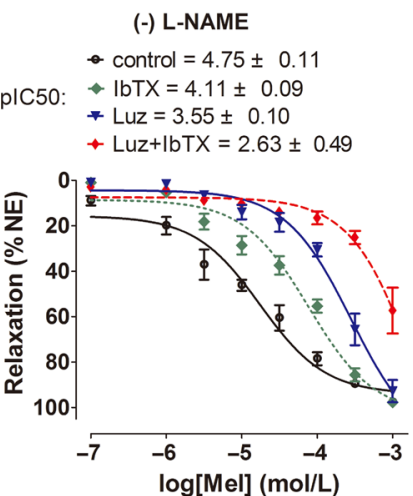

\section{MT2R}

C

a
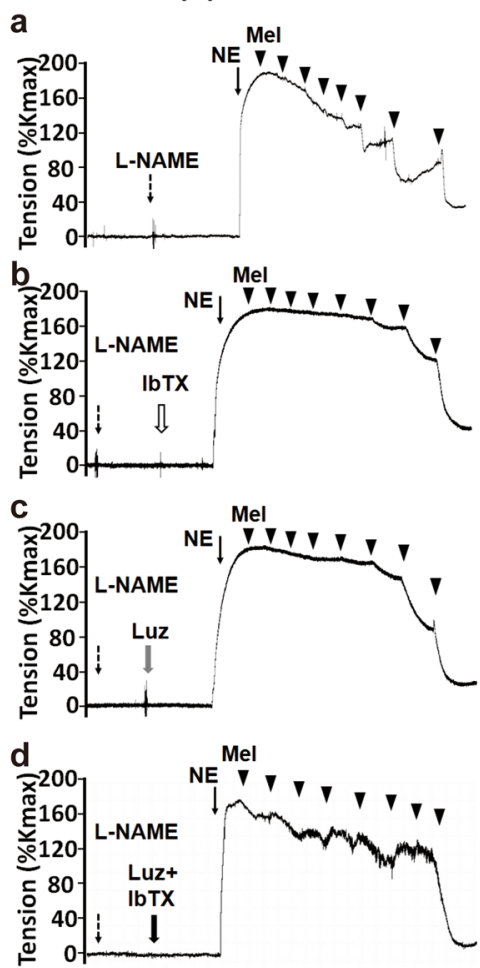

F

(+) L-NAME

$\rightarrow$ control $=3.93 \pm 0.12$

$\rightarrow \mathrm{IbTX}=2.74 \pm 0.13$

$*$ Luz $=3.36 \pm 0.12$

+ Luz+lbTX $=3.01 \pm 0.26$

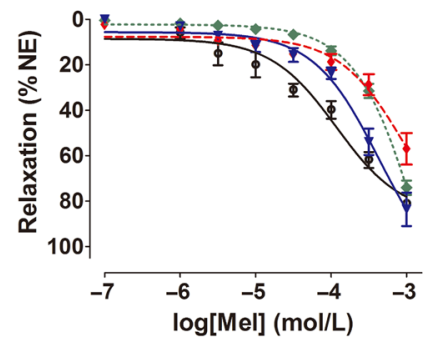

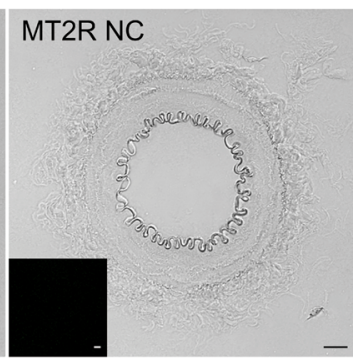

Denuded

a
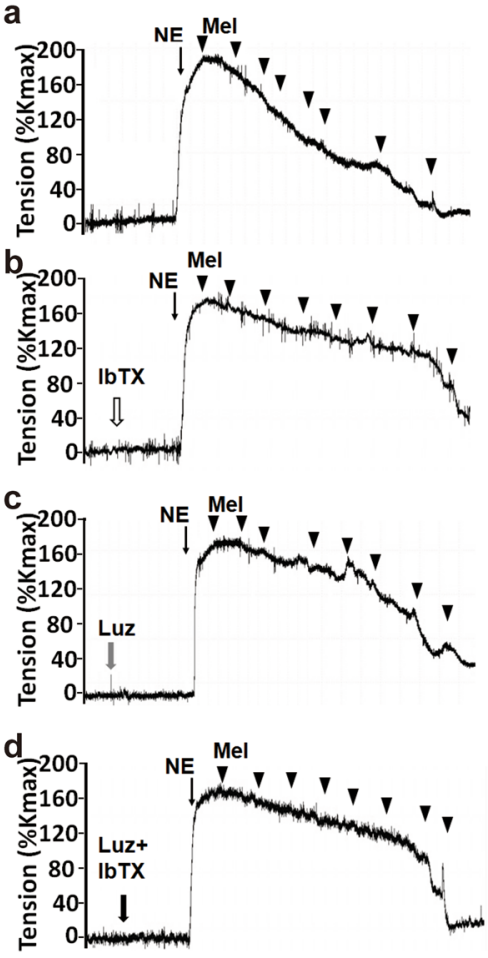

G

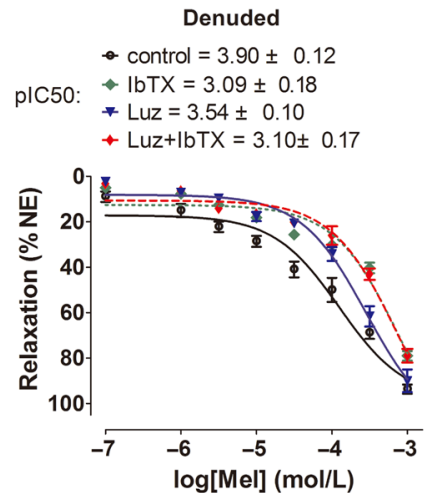

Figure 1

Expression of MT1/MT2 receptors and melatonin-induced vasodilation on MAs. (A) Immunofluorescence images of MT1 (red) and MT2 (green) receptors in MAs. The black and white pictures are the negative control (NC) images of MAs with secondary antibody only, no corresponding MT1 and MT2 receptor primary antibody. Scale bar $=20 \mu \mathrm{m}$. (B, C and D) Representative tracings of the effect of melatonin on NE (10-5 M)-induced vasoconstriction in the absence (B) or presence (C) of L-NAME $(100 \mu \mathrm{M})$, or in the denuded vessels (D). (a) Control; (b) IbTX-treated group; (c) Luz-treated group;

(d) Luz + IbTX-treated group. L-NAME, non-selective nitric oxide synthase inhibitor $\left.N^{\omega-n i t r o-l-a r g i n i n e ~ m e t h y l ~ e s t e r ; ~ I b T X, ~ i b e r i o t o x i n ~(10-8 ~} \mathrm{M}\right)$, BK ${ }_{\mathrm{Ca}}$ channel blocker; Luz, Luzindole $\left(2 \times 10^{-6} \mathrm{M}\right), \mathrm{MT1} / \mathrm{MT} 2$ receptor blocker. Black triangles mark the time of addition of melatonin $\left(10^{-7}, 10^{-6}, 3 \times 10^{-6}, 10^{-5}\right.$, $\left.3 \times 10^{-5}, 10^{-4}, 3 \times 10^{-4}, 10^{-3} \mathrm{M}\right)$. ( $\mathrm{E}, \mathrm{F}$ and G) Cumulative concentration-response curve for effects of melatonin on NE-induced contraction. $n=8$ in each group. Results are expressed as change in NE-induced vascular tone increase (\% NE). 
non-L-NAME-treated group $\left(\mathrm{pIC}_{50}=4.11 \pm 0.09\right)$. These results indicate that in addition to the activation of eNOS, melatonin-induced vasorelaxation is partially attributable to its activation of the $\mathrm{BK}_{\mathrm{Ca}}$ channels on vascular smooth muscle cells (VSMCs).

To determine whether the vasorelaxation induced by melatonin in MAs occurred through MT receptors, luzindole (MT1 and MT2 receptor blocker) was applied to the preparations before NE. As shown in Fig. 1B and $\mathrm{C}$, in both the L-NAME-treated and untreated groups, $2 \times 10^{-6} \mathrm{M}$ luzindole did not change the resting tension. However, after 2 -min incubation with luzindole, a parallel rightward shift of the melatonin concentration-relaxation curve was detected in both the L-NAME-treated and untreated groups, compared to those without luzindole incubation (Fig. 1E and F). The $\mathrm{pIC}_{50}$ was $3.55 \pm 0.10$ in the (-) L-NAME + Luz group, which was lower than that in the group without luzindole treatment $\left((-)\right.$ L-NAME: $\mathrm{pIC}_{50}=4.75 \pm 0.11$, both $n=8, P<0.01)$. The $\mathrm{pIC}_{50}$ was $3.36 \pm 0.12$ in the (+) L-NAME + Luz group, which was also lower than that in the group without luzindole treatment $((+)$ L-NAME: $\mathrm{pIC}_{50}=3.93 \pm 0.12, P<0.01, n=8$ in each group). These results indicate that melatonin-induced vasorelaxation may operate partially through the binding of melatonin to MT receptors. Unlike with IbTX, following luzindole incubation, the melatonin concentration-relaxation curve was not significantly shifted in the $(+)$ L-NAME group $\left(\mathrm{pIC}_{50}=3.36 \pm 0.12\right)$ compared to that of the nonL-NAME-treated group ( $\left.\mathrm{pIC}_{50}=3.55 \pm 0.10\right)$. These results indicate that in melatonin-induced vasorelaxation, the eNOS-dependent part occurs through MT receptors. Therefore, if the MT receptors are blocked by luzindole, there is no significant difference between the (+) L-NAME and (-) L-NAME groups. Iberiotoxin when combined with luzindole provided an additional inhibition of relaxation as compared to luzindole alone in either (-) L-NAME or (+) L-NAME group (Fig. 1B, $\mathrm{C}, \mathrm{E}$ and F). Another implication of the results is that melatonin-induced partial vasorelaxation, which depends on myocyte $\mathrm{BK}_{\mathrm{Ca}}$ channel activation, involves both MT receptor-mediated and non-MT receptormediated mechanisms.

Since endothelium-dependent component in the vascular bed also includes NO-independent endotheliumderived hyperpolarizing factor (EDHF) mechanism, the vasorelaxation effect of melatonin was also investigated on de-endothelized MAs. As shown in Fig. 1D and G, the vasodilation induced by melatonin was not significantly different from that in (+) L-NAME group, which indicates that EDHF mechanisms may not be involved in melatonininduced vasorelaxation of MAs.

\section{Melatonin increases whole-cell $\mathrm{BK}_{\mathrm{Ca}}$ currents in MA SMCs}

To compensate for differences in cell size, membrane $I_{K}$ is expressed relative to cell capacitance $(\mathrm{pA} / \mathrm{pF})$. To assess the effects of melatonin on $\mathrm{BK}_{\mathrm{Ca}}$ or $\mathrm{K}_{\mathrm{V}}$ components, the selective $\mathrm{BK}_{\mathrm{Ca}}$ channel inhibitor IbTX $(100 \mathrm{nM})$ or selective $\mathrm{K}_{\mathrm{V}}$ channel inhibitor 4 -AP $(3 \mathrm{mM})$ was applied first to the cells, and then melatonin $(10$ and $100 \mu \mathrm{M})$ was applied in the presence of IbTX or 4-AP (Fig. 2). As shown in Fig. 2A, $\mathrm{B}, \mathrm{C}$ and D, either 4-AP or IbTX suppressed the currents. At the holding potential (HP) of $+80 \mathrm{mV}$, the currents were inhibited by 4 -AP to $72.05 \pm 5.60 \%$ of control and by IbTX to $27.60 \pm 2.90 \%$ of control, respectively ( $n=12$ cells $/ 6$ rats), indicating that the outward $\mathrm{K}^{+}$currents consisted of at least two components: 4-AP-sensitive $\left(\mathrm{K}_{\mathrm{V}}\right)$ and IbTXsensitive ones $\left(\mathrm{BK}_{\mathrm{Ca}}\right)$. After 4-AP incubation, the outward $\mathrm{K}^{+}$current density was significantly inhibited, and the following melatonin increased the left parts (mainly $\mathrm{BK}_{\mathrm{Ca}}$ currents) significantly in a dose-dependent manner. At an $\mathrm{HP}$ of $+80 \mathrm{mV}$, the peak $\mathrm{BK}_{\mathrm{Ca}}$ current density was increased from $20.99 \pm 2.20 \mathrm{pA} / \mathrm{pF}$ to $32.08 \pm 3.10 \mathrm{pA} / \mathrm{pF}$ and $46.17 \pm 3.80 \mathrm{pA} / \mathrm{pF}$ after $10 \mu \mathrm{M}$ and $100 \mu \mathrm{M}$ melatonin treatment (each $n=12$ cells/6 rats, both $P<0.01$ ), respectively (Fig. 2A and B). As shown in Fig. 2C and D, after IbTX pretreatment, the whole-cell $\mathrm{I}_{\mathrm{K}}$ was markedly inhibited. The inhibited parts are IbTX-sensitive currents $\left(\mathrm{BK}_{\mathrm{Ca}}\right)$, and the left parts are mainly $\mathrm{K}_{\mathrm{V}}$ currents. However, the melatonin applied after IbTX pretreatment had no significant change on $\mathrm{K}_{\mathrm{V}}$ currents. These data indicate that melatonin activates BKCa channels but not KV channels.

To examine whether the activation of $\mathrm{BK}_{\mathrm{Ca}}$ channels is through MT1/MT2 receptors, luzindole $\left(2 \times 10^{-6} \mathrm{M}\right)$ was applied before melatonin. As shown in Fig. $2 \mathrm{E}$ and $\mathrm{F}$, luzindole had no significant change on $\mathrm{BK}_{\mathrm{Ca}}$ currents. At $\mathrm{HP}=+80 \mathrm{mV}$, after luzindole treatment, the peak $\mathrm{BK}_{\mathrm{Ca}}$ current density was increased from $20.64 \pm 2.13 \mathrm{pA} / \mathrm{pF}$ to $36.37 \pm 3.51 \mathrm{pA} / \mathrm{pF}$ by $100 \mu \mathrm{M}$ melatonin. The increase by melatonin was significantly inhibited by luzindole compared to that of control (from $22.65 \pm 2.40 \mathrm{pA} / \mathrm{pF}$ to $44.64 \pm 3.50 \mathrm{pA} / \mathrm{pF}$ by $100 \mu \mathrm{M}$ melatonin, each $n=6$, $P<0.01$ ), suggesting that the activation of $\mathrm{BK}_{\mathrm{Ca}}$ currents by melatonin was mediated by MT1/MT2 receptors.
() 2017 Society for Endocrinology Printed in Great Britain
Published by Bioscientifica Ltd 
A

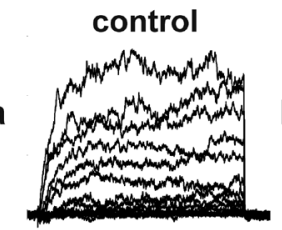

4-AP +

Mel (10 uM)
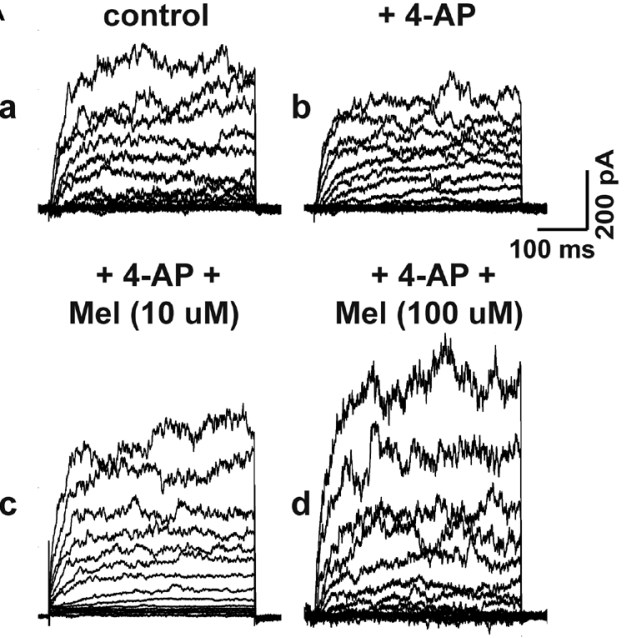

+ 4-AP +

Mel (100 uM)

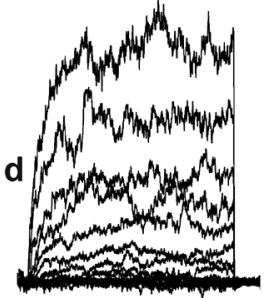

C

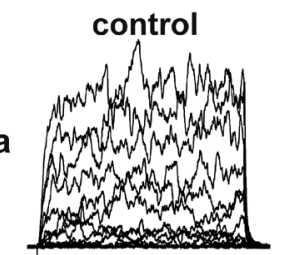

$+\mathrm{IbTX}$

b

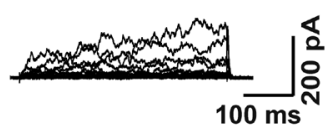

+ lbTX +

Mel (10 uM)

C

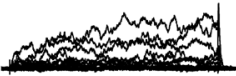

d

+ IbTX +

Mel (100 uM)

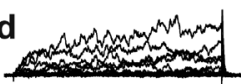

B

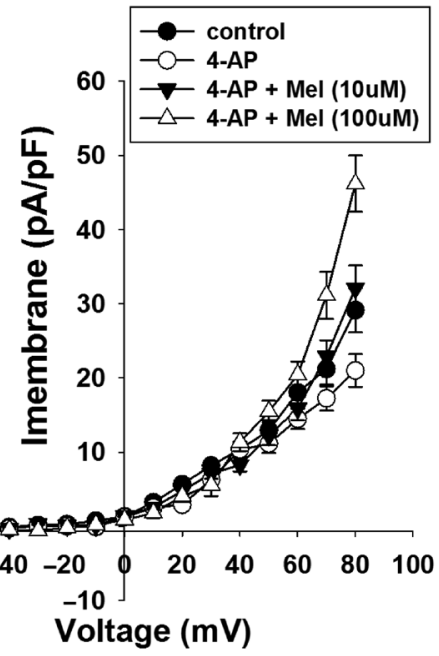

D

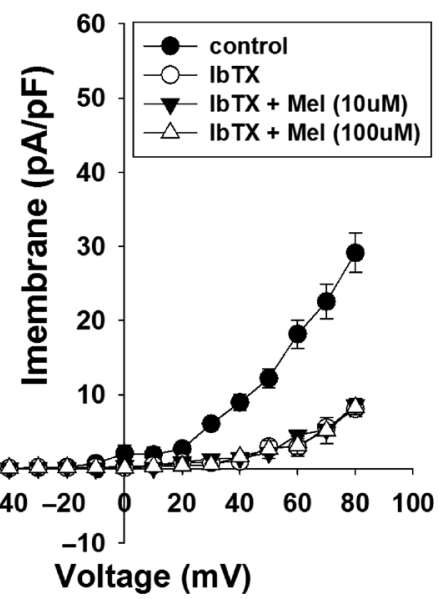

$\mathrm{E}$ + 4-AP

a

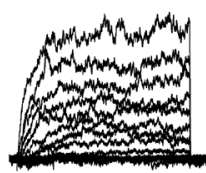

b

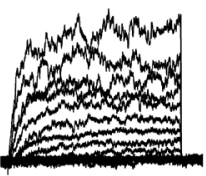

+ 4-AP

DMSO

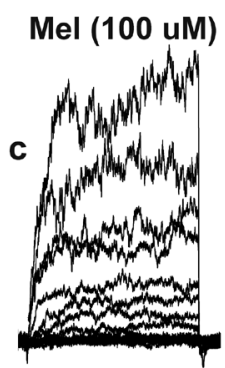

\section{$F$}
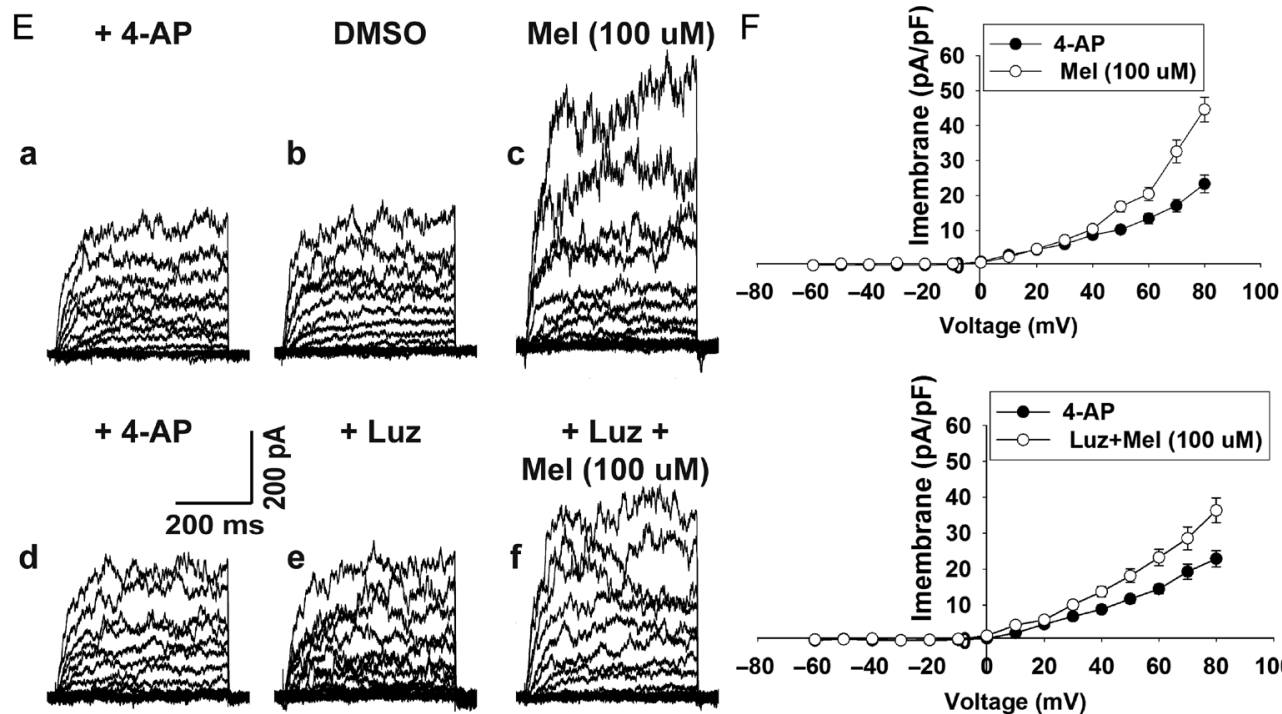

+ Luz +

Mel (100 uM)
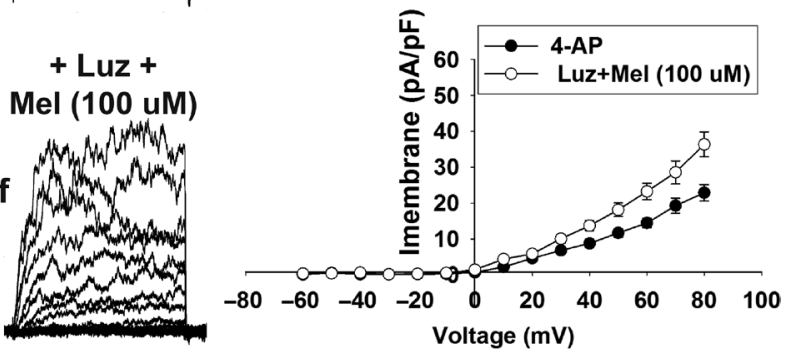

Figure 2

Melatonin increases the whole-cell BK $\mathrm{Ca}_{\mathrm{a}}$ currents in MA SMCs. (A and C) Whole-cell $\mathrm{I}_{\mathrm{K}}$ recorded in the presence of 4-aminopyridine (4-AP, 3 mM) or iberiotoxin (IbTX, 100 nM). Representative currents recorded in response to $400 \mathrm{~ms}$ voltage clamp steps from -60 to $+80 \mathrm{mV}$ in $10 \mathrm{mV}$ steps. (B and $\mathrm{D}$ ) Current-voltage relationships showing the effect of melatonin $(10 \mu \mathrm{M}$ and $100 \mu \mathrm{M})$ on the whole-cell $\mathrm{I}_{\mathrm{K}}$ density in the presence of 4 -AP or IbTX (each $n=12$ cells $/ 6$ rats). ( $E$ and $F$ ) The effects of luzindole on the melatonin-induced increase of the whole-cell BK ${ }_{C a}$ currents in MA SMCs. All the whole-cell $I_{K}$ was recorded in the presence of 4-AP $(3 \mathrm{mM})$ together with vehicle (DMSO, $0.1 \%)$, luzindole $\left(2 \times 10^{-6} \mathrm{M}\right)$, MT1/MT2 receptor blocker. See text for further details. 
A

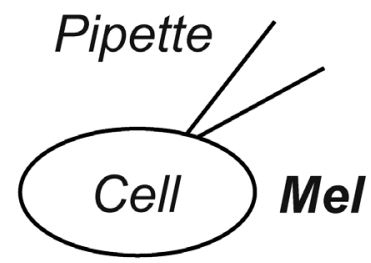

B

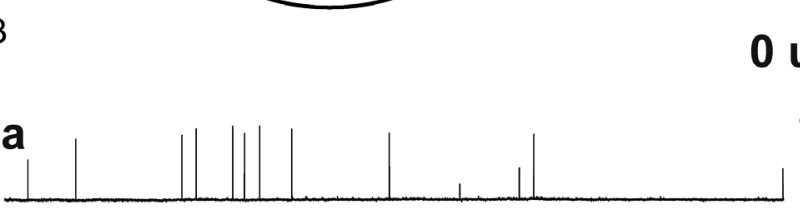

b

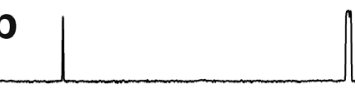

Cell-attached

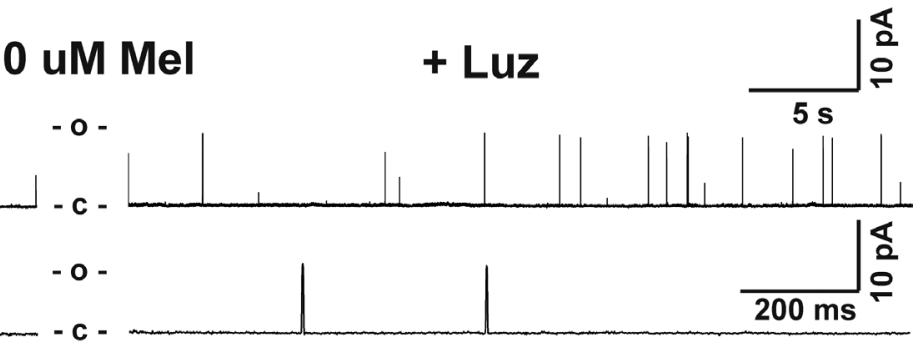

\section{0 uM Mel}

\section{a}

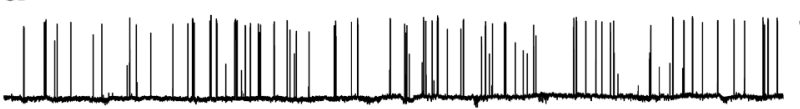

b

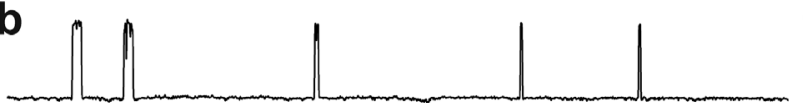

-0 -

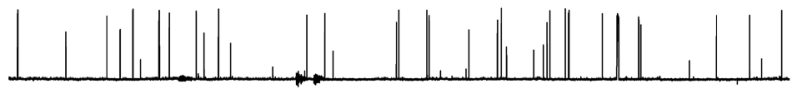

o -

a

\section{0 uM Mel}
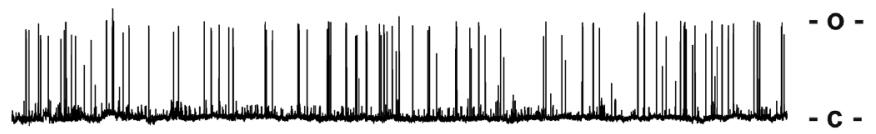

b

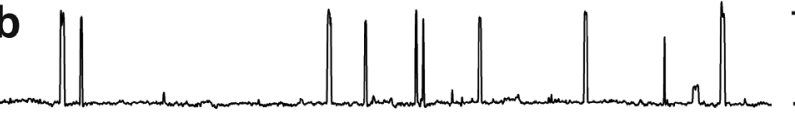

- 0 -
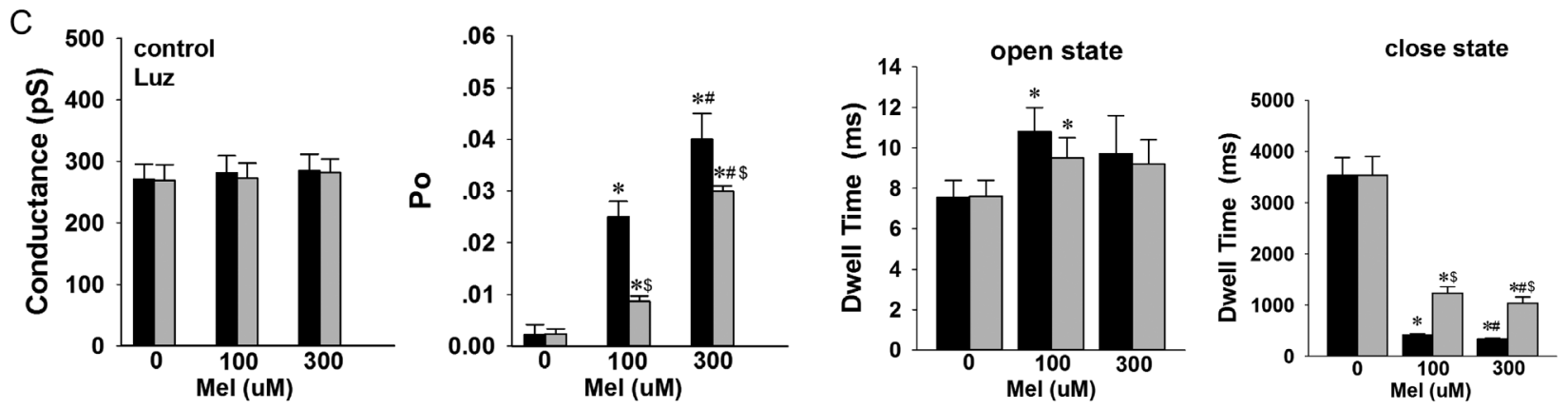

Figure 3

Melatonin increased the activity of $\mathrm{BK}_{\mathrm{Ca}}$ channels from mesenteric arterial myocytes in cell-attached patch-clamp configuration. $\left[\mathrm{Ca}^{2+}\right]_{\text {free }}$ in bath was $0.1 \mu \mathrm{M}$. The upward deflection indicates outward currents. (A) A schematic model showing the cell-attached patch-clamp configuration. (B) Representative recordings of single-channel currents at a membrane voltage of $+40 \mathrm{mV}$ in the presence of melatonin (left panel) or luzindole plus melatonin (right panel). Mel: melatonin, 0, 100, 300 MM; Luz: Luzindole, $2 \times 10^{-6} \mathrm{M}$. Traces shown are $50 \mathrm{~s}$ (a) or $2 \mathrm{~s}$ (b) recordings. (C) Summary of the conductance, Po, dwell time of open state and closed state $(n=8)$. Po: open probability. ${ }^{*} P<0.01$ vs control $(0 \mu \mathrm{M}$ melatonin). $\# P<0.01$ vs $100 \mu \mathrm{M}$ melatonin. $\$ P<0.01$, Luz + melatonin treatment vs melatonin-only treatment with same concentration. 


\section{Activation of $\mathrm{BK}_{\mathrm{Ca}}$ channel in MA SMC by melatonin in cell-attached patches}

Using cell-attached patch-clamp recording (Fig. 3A), we examined the effect of melatonin on $\mathrm{BK}_{\mathrm{Ca}}$ channel activity and gating properties. Figure $3 \mathrm{~B}$ shows representative records of single $\mathrm{BK}_{\mathrm{Ca}}$ channels under cellattached configuration with symmetrical $145 \mathrm{mM} \mathrm{K}^{+}$at a HP of $+40 \mathrm{mV}\left(\left[\mathrm{Ca}^{2+}\right]_{\text {free }}=0.1 \mu \mathrm{M}\right)$. Po increased along with membrane potential (data not shown). A linear fit revealed an average single-channel conductance $(\mathrm{G})$ of $270.8 \pm 24.5 \mathrm{pS}(n=8)$. Melatonin $(100$ and $300 \mu \mathrm{M})$ had no significant impact on the channel conductance (Fig. 3C).

Melatonin significantly increased the Po of $\mathrm{BK}_{\mathrm{Ca}}$ channels in a concentration-dependent manner. For example, with $100 \mu \mathrm{M}$ melatonin treatment, the Po $(0.025 \pm 0.003, n=8)$ was significantly increased compared with that of the control $(0.002 \pm 0.002, n=8, P<0.01)$, whereas $300 \mu \mathrm{M}$ melatonin increased the Po to $0.040 \pm 0.005$ $(n=8)$. To examine whether the activation of $\mathrm{BK}_{\mathrm{Ca}}$ channels occurred through MT1/MT2 receptors, luzindole $\left(2 \times 10^{-6} \mathrm{M}\right)$ was applied before melatonin. Luzindole significantly inhibited the increase of Po of $\mathrm{BK}_{\mathrm{Ca}}$ channels induced by melatonin $(100 \mu \mathrm{M}$ melatonin: $\mathrm{Po}=0.009 \pm 0.001 ; 300 \mu \mathrm{M}$ melatonin: $\mathrm{Po}=0.030 \pm 0.001$; both $n=8, P<0.01$ vs control). Luzindole itself had no significant impact on the activity of $\mathrm{BK}_{\mathrm{Ca}}$ channels; however, it could markedly inhibit the Po increase induced by melatonin. The conductance of $\mathrm{BK}_{\mathrm{Ca}}$ was unaffected by luzindole.

We further examined the effects of melatonin on the gating properties of the $\mathrm{BK}_{\mathrm{Ca}}$ channels in cell-attached patch configuration ( $n=8$ in each group). At the testing potential of $+40 \mathrm{mV}$, the Po was significantly increased in the melatonin treatment group (Fig. 3B and C). The mean open time (To) of a single $\mathrm{BK}_{\mathrm{Ca}}$ channel was increased in the $100 \mu \mathrm{M}$ melatonin treatment group $(10.80 \pm 1.20 \mathrm{~ms})$ compared with the control group $(7.54 \pm 0.85 \mathrm{~ms})$, but not significantly changed in the $300 \mu \mathrm{M}$ melatonin treatment group $(9.70 \pm 1.90 \mathrm{~ms})$. The mean close time (Tc) was significantly decreased in both the 100 and $300 \mu \mathrm{M}$ melatonin treatment groups $(411.60 \pm 34.50 \mathrm{~ms}$ and $337.90 \pm 21.30 \mathrm{~ms}$, respectively) compared with the control group ( $3531.95 \pm 350.60 \mathrm{~ms}, n=8$ in each group). These data show that luzindole inhibits Po increase mainly by prolonging the closed state of $\mathrm{BK}_{\mathrm{Ca}}$ channels.

\section{Activation of $\mathrm{BK}_{\mathrm{Ca}}$ channel by melatonin in inside-out patches}

We also examined the effect of melatonin on $\mathrm{BK}_{\mathrm{Ca}}$ channel activity and gating properties in an inside-out patch-clamp configuration (Fig. 4). Since the $\mathrm{BK}_{\mathrm{Ca}}$ activation induced by melatonin is much stronger in an inside-out patchclamp configuration than in a cell-attached configuration, lower concentrations of melatonin $(10,30,100 \mu \mathrm{M})$ were used here. Figure $4 \mathrm{~A}$ shows representative records of single $\mathrm{BK}_{\mathrm{Ca}}$ channels in an inside-out configuration at different voltages with symmetrical $145 \mathrm{mM} \mathrm{K}^{+}$in the presence of $0.1 \mu \mathrm{M}$ and $1 \mu \mathrm{M} \mathrm{Ca}^{2+}$ with or without melatonin $(0,10,30$, $100 \mu \mathrm{M})$. A linear fit revealed an average single-channel conductance $(\mathrm{G})$ of $279.3 \pm 45.0 \mathrm{pS}\left(\left[\mathrm{Ca}^{2+}\right]_{\text {free }}=0.1 \mu \mathrm{M}, n=8\right)$ and $305.5 \pm 48.0 \mathrm{pS}\left(\left[\mathrm{Ca}^{2+}\right]_{\text {free }}=1 \mu \mathrm{M}, n=8\right)$, respectively. Melatonin $(10,30,100 \mu \mathrm{M})$ had no significant effect on the channel conductance (Fig. 4B).

We further examined the effects of melatonin at different doses on the gating properties of the $\mathrm{BK}_{\mathrm{Ca}}$ channels (Fig. 4B, $n=8$ in each group). At the testing potential of $+40 \mathrm{mV}$, the Po was significantly increased by melatonin in a concentration-dependent manner. When the $\left[\mathrm{Ca}^{2+}\right]_{\text {free }}=0.1 \mu \mathrm{M}$, the mean open time (To) of a single $\mathrm{BK}_{\mathrm{Ca}}$ channel was longer in the melatonin group than in the control group $(7.77 \pm 0.80 \mathrm{~ms}(10 \mu \mathrm{M}$ melatonin $)$, $9.92 \pm 1.20 \mathrm{~ms} \quad(30 \mu \mathrm{M}), \quad 16.44 \pm 1.82 \mathrm{~ms} \quad(100 \mu \mathrm{M}) \quad$ vs $4.96 \pm 0.40 \mathrm{~ms}$ (control); all $P<0.01$ ). The Tc was shorter in the melatonin group than in the control group $(208.10 \pm 21.20 \mathrm{~ms}(10 \mu \mathrm{M}$ melatonin $), 155.80 \pm 25.60 \mathrm{~ms}$ $(30 \mu \mathrm{M}), \quad 51.46 \pm 6.70 \mathrm{~ms}(100 \mu \mathrm{M})$ vs $251.20 \pm 19.60 \mathrm{~ms}$ (control), all $P<0.01)$. In summary, melatonin treatment decreases Tc and increases To in a dose-dependent manner. When the $\left[\mathrm{Ca}^{2+}\right]_{\text {free }}=1 \mu \mathrm{M}$, melatonin treatment also decreases Tc and increases To, which is most prominent in $100 \mu \mathrm{M}$ melatonin.

The influence of melatonin on the voltage and calcium dependence of the $\mathrm{BK}_{\mathrm{Ca}}$ channels was also examined (Fig. 5). Notably, Po increased along with membrane potential (Fig. 5A). The NPo was normalized to the max probability. The Po-voltage relationships were fitted with the Boltzmann distribution to determine the voltage for half activation of the channel, $V_{1 / 2}$ (equation described in 'Materials and methods' section). As can be seen from Fig. 5B, $V_{1 / 2}$ was shifted from $54.78 \pm 0.56 \mathrm{mV}$ (control) to $44.47 \pm 0.52 \mathrm{mV}$ by $10 \mu \mathrm{M}$ melatonin, and to $30.44 \pm 0.48 \mathrm{mV}$ by $100 \mu \mathrm{M}$ melatonin $\left(0.1 \mu \mathrm{M}\left[\mathrm{Ca}^{2+}\right]_{\text {free }}\right)$. However, melatonin had no significant effect on the slope.

A similar leftward shift in $\mathrm{Ca}^{2+}$-dependent activation was observed with melatonin treatment. Figure 5C plots the relations of NPo normalized to their maximum value against $\left[\mathrm{Ca}^{2+}\right]_{\text {free }}$. The Po-Ca ${ }^{2+}$ curve fitted (using least squares) by Hill equation with a $K_{d}$ value of $1.90 \pm 0.10$ (control), $1.35 \pm 0.11(10 \mu \mathrm{M}$ Melatonin) and $0.32 \pm 0.02$ $(100 \mu \mathrm{M}$ Melatonin, $n=6$ in each group), respectively.

Published by Bioscientifica Ltd. 
A

Inside-out

$$
\left[\mathrm{Ca}^{2+}\right]_{\text {free }}=0.1 \mathrm{uM}
$$

O uM Mel

$$
\left[\mathrm{Ca}^{2+}\right]_{\text {free }}=1 \mathrm{uM}
$$

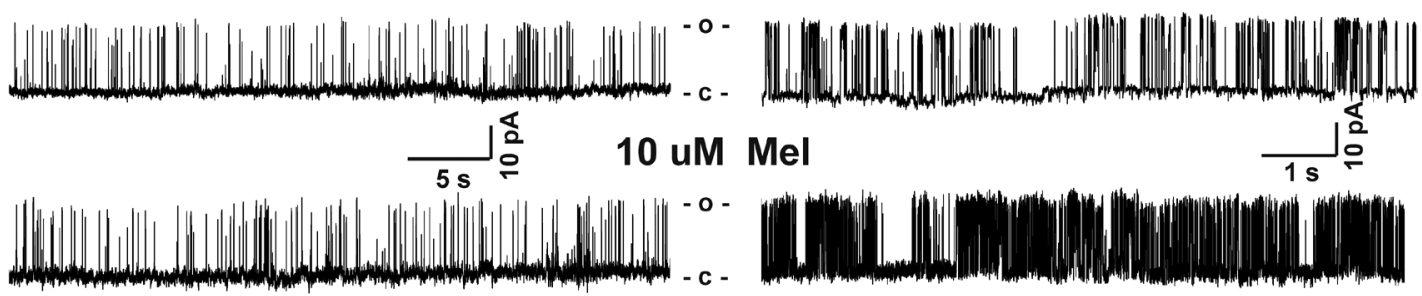

\section{0 uM Mel}
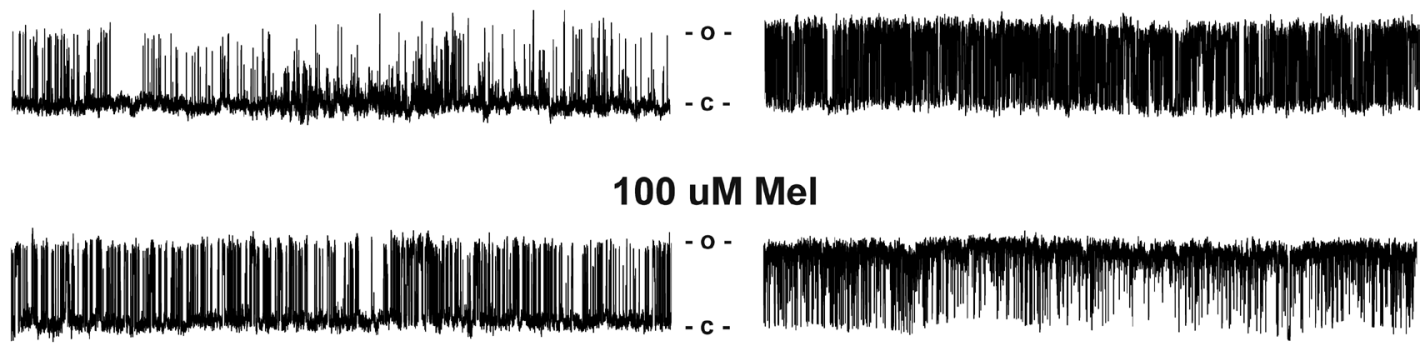

B
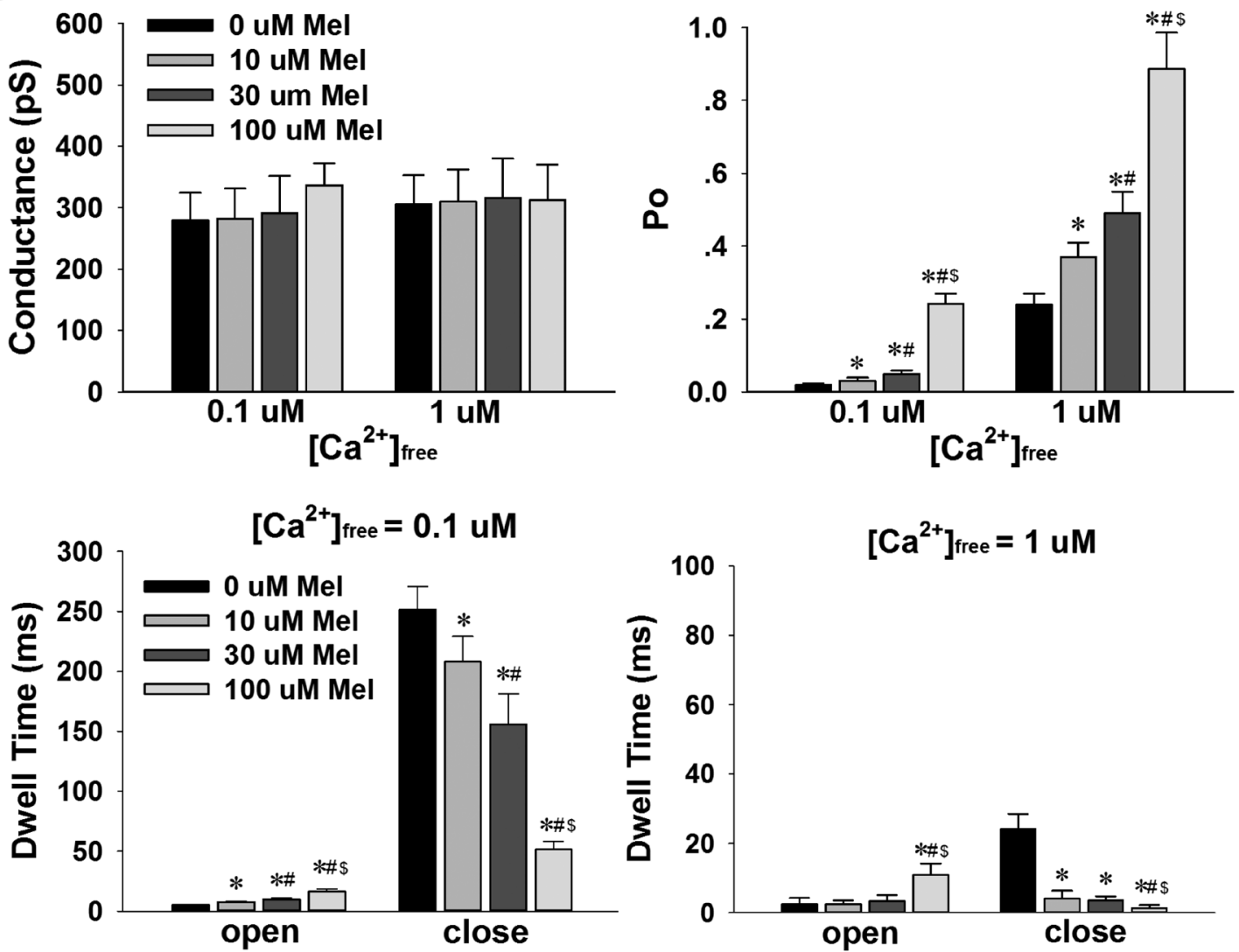

Figure 4

Melatonin increased the activity of $\mathrm{BK}_{\mathrm{Ca}}$ channels from mesenteric arterial myocytes in inside-out patch-clamp configuration. The upward deflection indicates outward currents. (A) Representative recordings of single-channel currents at a membrane voltage of $+40 \mathrm{mV}$ in the presence or absence of melatonin $(0,10,30$ and $100 \mu \mathrm{M})$. [Ca $\left.{ }^{2+}\right]_{\text {free }}$ in bath was $0.1 \mu \mathrm{M}$ (left) or $1 \mu \mathrm{M}$ (right). (B) Summary of the Conductance, Po, Dwell time of open state and closed state $(n=8)$. Po: open probability. ${ }^{*} P<0.01$ vs control $\left(0 \mu \mathrm{M}\right.$ melatonin). ${ }^{P} P<0.01$ vs $10 \mu \mathrm{M}$ melatonin. $\$ P<0.01$ vs $30 \mu \mathrm{M}$ melatonin. 
A Inside-out

control

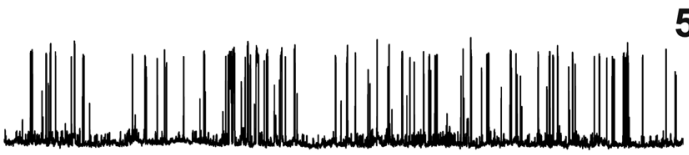

$50 \mathrm{mV}$

100 uM Mel

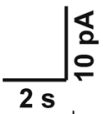

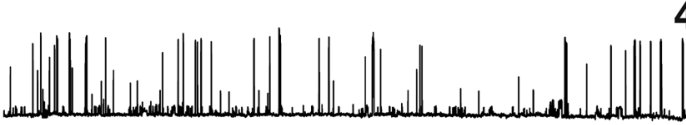

$40 \mathrm{mV}$
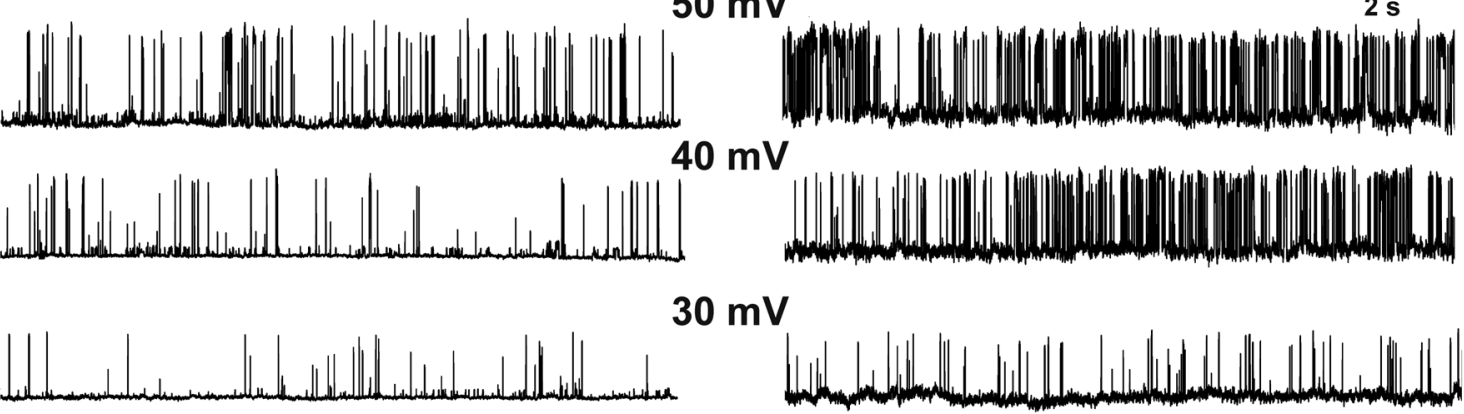

$20 \mathrm{mV}$

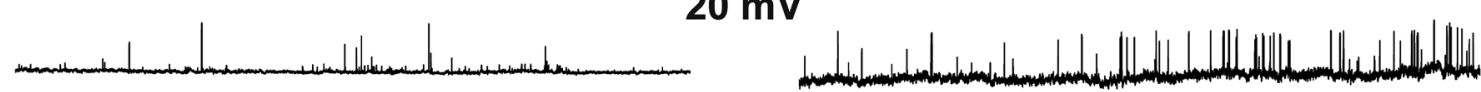

$10 \mathrm{mV}$

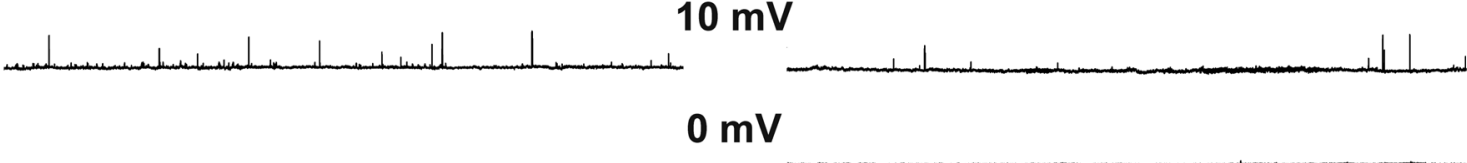

$-10 \mathrm{mV}$

B

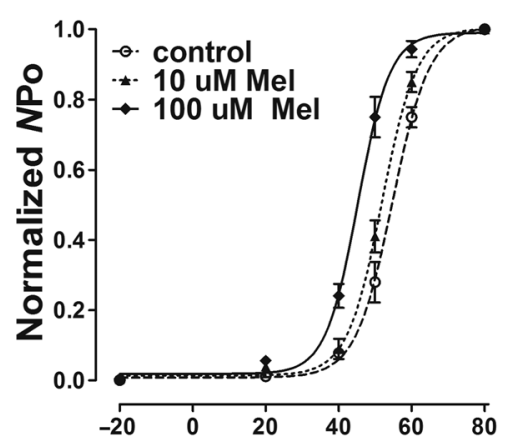

Membrane Voltage (mV)
C

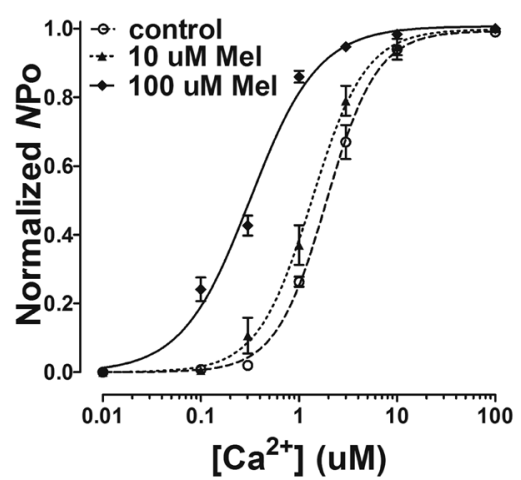

E

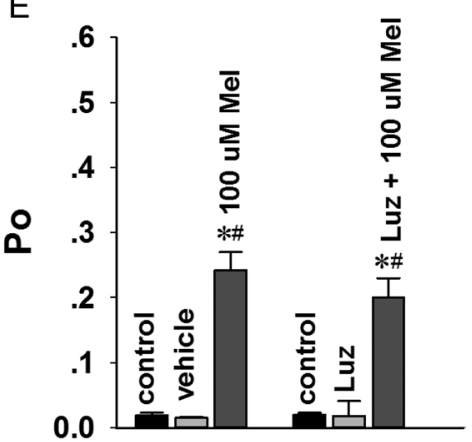

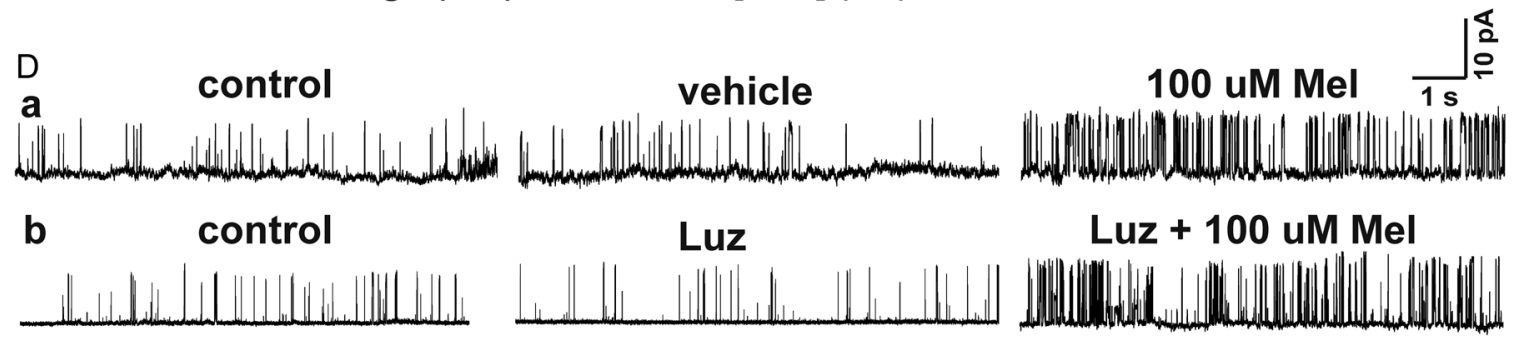

Figure $\mathbf{5}$

Effect of melatonin on voltage and calcium dependence of $\mathrm{BK}_{\mathrm{Ca}}$ channels in mesenteric arterial myocytes in inside-out patch-clamp configuration. (A) Representative recordings of single-channel currents in the presence of melatonin $(100 \mu \mathrm{M})$ at different membrane voltages $(-10$ to $50 \mathrm{mV})$. [Ca2+ $]_{\text {free }}$ in bath was $0.1 \mu \mathrm{M}$. (B) Effect of melatonin $(0,10,100 \mu \mathrm{M})$ on voltage dependence of $\mathrm{BK}_{\mathrm{Ca}}$ channels. The line was drawn according to the best fit with the Boltzmann equation (Eq. 1, $n=8)$. (C) Effect of melatonin $(0,10$ and $100 \mu \mathrm{M})$ on calcium dependence of $B K_{C a}$ channels. $H P=+40 \mathrm{mV}$. The data points were fitted with the Hill equation (Eq. 2) to obtain the calcium concentration necessary to open half of the channels $(K d)$ and the Hill coefficient $\left(\eta^{H}\right)$. (D) Luzindole has no significant effect on melatonin-induced increase of Po in inside-out patch-clamp configuration. $\mathrm{HP}=+40 \mathrm{mV},\left[\mathrm{Ca}{ }^{2+}\right]_{\text {free }}=0.1 \mu \mathrm{M}$. Vehicle: DMSO (0.1\%); Luz: $2 \times 10^{-6} \mathrm{M}$. (E) Bar plot summarizes luzindole on melatonin-induced increase of Po in inside-out patch-clamp configuration. $* P<0.01$ vs control; $\# P<0.01$, vs vehicle (a) or Luz (b). $n=6$ in each group. 
The Hill coefficient $(H)$ was $1.67 \pm 0.12$ (control), $1.57 \pm 0.17(10 \mu \mathrm{M}$ Melatonin) and $1.25 \pm 0.11(100 \mu \mathrm{M}$ Melatonin).

To rule out the direct effect of luzindole on single $\mathrm{BK}_{\mathrm{Ca}}$ channels, we examined the effects of luzindole on single $\mathrm{BK}_{\mathrm{Ca}}$ channels in inside-out configuration (Fig. 5D and $\mathrm{E})$. Luzindole $\left(2 \times 10^{-6} \mathrm{M}\right)$ itself had no effect on single $\mathrm{BK}_{\mathrm{Ca}}$ activity in inside-out configuration. After luzindole pretreatment, the Po increase induced by melatonin $(100 \mu \mathrm{M})$ was not significantly changed.

\section{Discussion}

The results of this study demonstrate that (1) melatonin induces concentration-dependent vasodilation in MAs; (2) in addition to activating eNOS, melatonin significantly activates $\mathrm{BK}_{\mathrm{Ca}}$ channels on the mesenteric arterial SMCs; (3) this enhancement of $\mathrm{BK}_{\mathrm{Ca}}$ channel activity involves both direct and indirect (MT1/MT2 receptor-mediated) pathways. Thus, in MAs, vasodilation by melatonin depends on the activity of both endothelial factors and $\mathrm{BK}_{\mathrm{Ca}}$ channels. These findings suggest a novel but important pathway of melatonin in regulating vascular tone: passing through the cell membrane and activating the $\mathrm{BK}_{\mathrm{Ca}}$ channel directly.

Increasing evidence shows that melatonin exerts many of its physiological actions through interaction with MT1 and MT2 receptors, which belong to the G-protein-coupled family of membrane receptors (PandiPerumal et al. 2008, Tunstall et al. 2011). The different vascular effects observed with melatonin are attributed to the relative distribution of MT1 and MT2 receptors, since MT1 receptor activation causes vasoconstriction and MT2 receptor activation causes vasodilation (Doolen et al. 1998).

ENOS is primarily responsible for the generation of NO in the vascular endothelium (Fish et al. 2006). NO produced by eNOS in the vascular endothelium plays crucial roles in regulating vascular tone (Förstermann \& Münzel 2006). Hence, a functional eNOS is essential for a healthy cardiovascular system. Once produced in ECs, NO diffuses across the VSMC membranes and activates the enzyme-soluble guanylate cyclase (sGC), which catalyzes the conversion of guanosine triphosphate into cyclic guanosine monophosphate (cGMP) (Denninger \& Marletta 1999). CGMP, in turn, activates protein kinase G (PKG), which promotes multiple phosphorylation of cellular targets, lowering cellular $\mathrm{Ca}^{2+}$ concentrations and promoting vascular relaxation
(Cornwell et al. 1994). In this study, melatonin-induced vasodilation was significantly inhibited in the presence of L-NAME (eNOS inhibitor). Thus, vasodilation depends on the presence of NO released by the endothelium. This finding suggests that the endothelium (endotheliaderived NO) is a target for melatonin action. Melatonin increases NO availability (Paulis \& Simko 2007) to induce vasodilation, which is consistent with previous studies (Girouard et al. 2001).

In another experiment, we found that pretreatment of the MAs with luzindole (MT1/MT2 receptor inhibitor) also significantly inhibited melatonininduced vasorelaxation. This finding suggests that melatonin may act partially through MT receptors. However, the melatonin concentration-relaxation curve was not significantly shifted in the (+) L-NAME group $\left(\mathrm{pIC}_{50}=3.36 \pm 0.12\right)$ compared with the non-L-NAMEtreated group $\left(\mathrm{pIC}_{50}=3.55 \pm 0.10\right)$. These results suggest that in melatonin-induced vasorelaxation, the eNOSdependent part occurs mainly through MT receptors. Therefore, if the MT receptors are blocked by luzindole, there is no significant difference in $\mathrm{pIC}_{50}$ between the $(+)$ L-NAME and (-) L-NAME groups.

In addition to the endothelium, $\mathrm{BK}_{\mathrm{Ca}}$ channels on VSMCs also play an important role in vessel tone regulation (Bukiya et al. 2007). $\mathrm{BK}_{\mathrm{Ca}}$ channels are mainly activated and hyperpolarize the membrane, which, in turn, suppresses the activity of the voltage-gated $\mathrm{Ca}^{2+}$ channels and thereby relaxes the artery (Nelson \& Quayle 1995, Davis \& Hill 1999). In the present study, IbTX caused a parallel rightward shift of the melatonin concentrationrelaxation curve in both L-NAME-treated and untreated groups, which indicates that in addition to the activation of eNOS, melatonin-induced vasorelaxation is partially attributable to its activation of the $\mathrm{BK}_{\mathrm{Ca}}$ channels on VSMCs. Another interesting thing to be noted is that the NO-dependent component of relaxation appears sensitive to iberiotoxin too (Fig. 1). As reported, $\mathrm{BK}_{\mathrm{Ca}}$ channels are also detected in ECs in rat MAs, and the activation of $\mathrm{BK}_{\mathrm{Ca}}$ channels on ECs also induces vasodilation (JacksonWeaver et al. 2013). This may partially explain the sensitivity of NO-dependent component to iberiotoxin in the present study. Then, whether melatonin's action on $\mathrm{BK}_{\mathrm{Ca}}$ channels in VSMCs was receptor mediated or non-receptor mediated was still unclear. We found that in the presence of L-NAME, luzindole $\left(2 \times 10^{-6} \mathrm{M}\right)$ had no significant effect on MAs, but suppressed the vasodilation induced by melatonin. If melatonin-induced $\mathrm{BK}_{\mathrm{Ca}}$ activation were all through MT1/MT2 receptors, then

Published by Bioscientifica Ltd. 


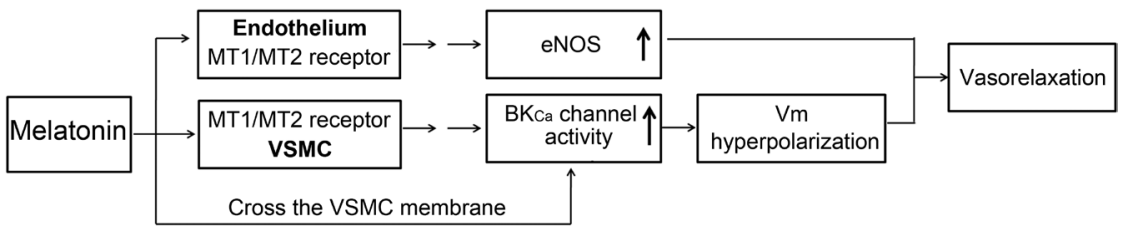

\begin{abstract}
Figure 6
A model for a mechanistic explanation of vasodilation of melatonin on MAs. Both endothelium-dependent and non-endotheliumdependent pathways are involved in melatonininduced vasodilation of MAs. In the endothelium-dependent pathway, by binding to MT1/MT2 receptors, melatonin enhances eNOS to reduce NO production, which induces partial vasodilation. In the non-endothelium-dependent pathway, melatonin causes vasodilation by activating $\mathrm{BK}_{\mathrm{Ca}}$ channels on VSMCs either directly or indirectly (via $\mathrm{MT} 1 / \mathrm{MT} 2$ receptors).
\end{abstract}

luzindole should abolish the vasodilation of melatonin in the presence of L-NAME. However, this was not the case. The melatonin concentration-relaxation curve was only rightshifted in the luzindole-treated group $\left(\mathrm{pIC}_{50}=3.36 \pm 0.12\right)$ compared with the control group $\left(\mathrm{pIC}_{50}=3.93 \pm 0.12\right)$. This finding indicates that melatonin-induced vasorelaxation dependent on myocyte $\mathrm{BK}_{\mathrm{Ca}}$ channel activation involves not only MT receptor-mediated mechanisms, but also non-MT receptor-mediated mechanisms.

Previous studies have demonstrated that melatonin constricts cerebral arteries (Geary et al. 1997) in vitro, following $\mathrm{G}$ protein-dependent inhibition of $\mathrm{Ca}^{2+}$-activated $\mathrm{BK}_{\mathrm{Ca}}$ channels. By using an open-skull preparation in anesthetized rats, Régrigny also showed that melatonin directly constricts small-diameter cerebral arterioles in rats (Régrigny et al. 1999). This vasoconstriction effect is mediated by the inhibition of $\mathrm{BK}_{\mathrm{Ca}}$ channels following activation of MT1 and/or MT2 receptors. Our results were not consistent with those findings. If melatonin inhibits $\mathrm{BK}_{\mathrm{Ca}}$ channels on mesenteric arterial myocytes, then melatonin should induce vasoconstriction. However, we found just the opposite effect: melatonin induced vasodilation in MAs. IbTX pretreatment significantly inhibited the melatonin-induced relaxation. These data suggest that melatonin activates, rather than inhibits, $\mathrm{BK}_{\mathrm{Ca}}$ channels on mesenteric arterial myocytes.

The mechanisms underlying melatonin-induced activation of $\mathrm{BK}_{\mathrm{Ca}}$ channels in MA myocytes were further studied using electrophysiological studies. Whole-cell recording showed that melatonin significantly increased $\mathrm{BK}_{\mathrm{Ca}}$ currents but not $\mathrm{K}_{\mathrm{V}}$ currents. In previous studies, both activation and inactivation of potassium channels by melatonin have been reported. For example, it was found that 2-indomelatonin (a melatonin receptor agonist) increased $\mathrm{BK}_{\mathrm{Ca}}$ channel activity in nonpregnant and pregnant rat uterine myocytes in the cell-attached patch-clamp configuration (Steffens et al. 2003). However, the effect on NPo was transient; 2 min after the addition of 2-iodomelatonin, the open probability had returned to the basal value. However, in this study, we found that melatonin had a sustained, concentration-dependent activating effect on $\mathrm{BK}_{\mathrm{Ca}}$ channels. A cell-attached patch clamp showed that melatonin significantly activated $\mathrm{BK}_{\mathrm{Ca}}$ channels. Blocking MT1/MT2 receptors by luzindole significantly inhibited the NPo increase, which suggests that melatonin acts at least partially by binding to MT receptors. Our vascular contraction experiments supported this theory: MT receptor blocker inhibited melatonin-induced vasorelaxation.

Melatonin is a highly permeant neutral molecule that can pass through the cell membrane rapidly. Due to its highly lipophilic nature, melatonin passes through cell membranes with ease (Yu et al. 2016). We speculated that melatonin could act on $\mathrm{BK}_{\mathrm{Ca}}$ channels directly. To evaluate this hypothesis, an inside-out patch clamp was conducted. The results clearly showed that melatonin could activate $\mathrm{BK}_{\mathrm{Ca}}$ channels directly. Our vessel contractility experiments with luzindole also lent strong support to this hypothesis. In the presence of L-NAME, both luzindole and IbTX pretreatment caused a parallel rightward shift of the melatonin concentration-relaxation curve (Luzindole: $\mathrm{pIC}_{50}=3.36 \pm 0.12$; IbTX: $\mathrm{pIC}_{50}=2.74 \pm 0.13$ ) compared with the control group $\left(\mathrm{pIC}_{50}=3.93 \pm 0.12\right)$. IbTX shifted the curve more than luzindole, which suggests that melatonin-induced activation of $\mathrm{BK}_{\mathrm{Ca}}$ channels occurs not only through binding to MT receptors but also through other means (non-receptor-mediated pathway). One possibility is that melatonin activates the $\mathrm{BK}_{\mathrm{Ca}}$ channel directly, just as our inside-out patch-clamp study demonstrated. In both the cell-attached and inside-out patch-clamp configuration, melatonin displayed an alteration of the gating properties on $\mathrm{BK}_{\mathrm{Ca}}$ channels by prolonging the time in the open state (To) and shortening the time in the closed state (Tc). In inside-out patch-clamp configuration, luzindole itself had no effect on single $\mathrm{BK}_{\mathrm{Ca}}$ activity. Moreover, luzindole pretreatment did not change

Published by Bioscientifica Ltd. 
the Po increase induced by melatonin, which can rule out the possibility that MT1/2 receptors are physically associated with $\mathrm{BK}_{\mathrm{Ca}}$ channel similar to thromboxane receptor and other channels (Li et al. 2010). However, it is still difficult to determine whether such a compound acts inside or outside of the cell. Usually, a highly permeant compound is observed on both sides of the membrane at almost equal concentrations, whether it is applied inside the cell or outside the cell (Yu et al. 2016).

Based on these findings, we propose a model for a mechanistic explanation of the vasodilation of melatonin on MAs (Fig. 6). First, in addition to the enhancement of eNOS on the endothelium, melatonin activates $\mathrm{BK}_{\mathrm{Ca}}$ channels on mesenteric arterial SMCs to induce vasodilation. Second, the activation of $\mathrm{BK}_{\mathrm{Ca}}$ channels by melatonin involves direct (non-receptormediated) and indirect (receptor-mediated) mechanisms. Melatonin can pass through the cell membrane with ease and provides on-site activation of $\mathrm{BK}_{\mathrm{Ca}}$ channels. As an inexpensive and well-tolerated drug, melatonin may be a new therapeutic option for cardiovascular diseases such as hypertension.

\section{Declaration of interest}

The authors declare that there is no conflict of interest that could be perceived as prejudicing the impartiality of the research reported.

\section{Funding}

This work was supported by the National Natural Science Foundation of China (31371201), the Beijing Natural Science Foundation (5172023), Research project of General Administration of Sport of China (2015B035) and the Chinese Universities Scientific Fund (2017ZD004).

\section{Author contribution statement}

L S and Y W participated in research design; T Z, H Z, C J and F Q conducted experiments; T Z, C J and F Q performed data analysis; T Z and L S wrote or contributed to the writing of the manuscript.

\section{References}

Anwar MM, Meki AR \& Rahma HH 2001 Inhibitory effects of melatonin on vascular reactivity: possible role of vasoactive mediators. Comparative Biochemistry and Physiology Part C: Toxicology \& Pharmacology 130 357-367 (doi:10.1016/s1532-0456(01)00261-7).

Bukiya AN, Liu J, Toro L \& Dopico AM 2007 $\beta 1$ (KCNMB1) subunits mediate Lithocholate activation of large-conductance $\mathrm{Ca}^{2+}$-Activated $\mathrm{K}^{+}$channels and dilation in small, resistance-size arteries. Molecular Pharmacology 72 359-369. (doi:10.1124/mol.107.034330)

Cook JS, Sauder CL \& Ray CA 2011 Melatonin differentially affects vascular blood flow in humans. American Journal of Physiology: Heart and Circulatory Physiology 300 H670-H674. (doi:10.1152/ ajpheart.00710.2010)

Cornwell TL, Arnold E, Boerth NJ \& Lincoln TM 1994 Inhibition of smooth muscle cell growth by nitric oxide and activation of cAMPdependent protein kinase by cGMP. American Journal of Physiology 267 C1405-C1413.

Davis MJ \& Hill MA 1999 Signaling mechanisms underlying the vascular myogenic response. Physiological Reviews 79 387-423.

Denninger JW \& Marletta MA 1999 Guanylate cyclase and the .NO/ cGMP signaling pathway. Biochimica et Biophysica Acta 1411 334-350. (doi:10.1016/S0005-2728(99)00024-9)

Doolen S, Krause DN, Dubocovich ML \& Duckles SP 1998 Melatonin mediates two distinct responses in vascular smooth muscle. European Journal of Pharmacology 345 67-69. (doi:10.1016/S00142999(98)00064-8)

Dubocovich ML, Rivera-Bermudez MA, Gerdin MJ \& Masana MI 2003 Molecular pharmacology, regulation and function of mammalian melatonin receptors. Frontiers in Bioscience 8 d1093-d1108. (doi:10.2741/1089)

Evans BK, Mason R \& Wilson VG 1992 Evidence for direct vasoconstrictor activity of melatonin in "pressurized" segments of isolated caudal artery from juvenile rats. Naunyn-Schmiedeberg's Archives of Pharmacology 346 362-365. (doi:10.1007/bf00173553)

Fish JE \& Marsden PA 2006 Endothelial nitric oxide synthase: insight into cell-specific gene regulation in the vascular endothelium. Cellular and Molecular Life Sciences 63 144-162. (doi:10.1007/s00018005-5421-8)

Förstermann U \& Münzel T 2006 Endothelial nitric oxide synthase in vascular disease: from marvel to menace. Circulation 113 1708-1714. (doi:10.1161/CIRCULATIONAHA.105.602532)

Geary GG, Krause DN \& Duckles SP 1997 Melatonin directly constricts rat cerebral arteries through modulation of potassium channels. American Journal of Physiology 273 H1530-H1536.

Geary GG, Duckles SP \& Krause DN 1998 Effect of melatonin in the rat tail artery: role of $\mathrm{K}+$ channels and endothelial factors. British Journal of Pharmacology 123 1533-1540. (doi:10.1038/sj. bjp.0701761)

Girouard H, Chulak C, Lejossec M, Lamontagne D \& de Champlain J 2001 Vasorelaxant effects of the chronic treatment with melatonin on mesenteric artery and aorta of spontaneously hypertensive rats. Journal of Hypertension 19 1369-1377. (doi:10.1097/00004872200108000-00004)

Grossini E, Molinari C, Uberti F, Mary DA, Vacca G \& Caimmi PP 2011 Intracoronary melatonin increases coronary blood flow and cardiac function through $\beta$-adrenoreceptors, MT1/MT2 receptors, and nitric oxide in anesthetized pigs. Journal of Pineal Research 51 246-257. (doi:10.1111/j.1600-079X.2011.00886.x)

Hamill OP, Marty A, Neher E, Sakmann B \& Sigworth FJ 1981 Improved patch-clamp techniques for high-resolution current recording from cell and cell-free membrane patches. Pflügers Archiv 391 85-100. (doi.10.1007/bf00656997)

Hung MW, Kravtsov GM, Lau CF, Poon AM, Tipoe GL \& Fung ML 2013 Melatonin ameliorates endothelial dysfunction, vascular inflammation, and systemic hypertension in rats with chronic intermittent hypoxia. Journal of Pineal Research 55 247-256. (doi:10.1111/jpi.12067)

Jackson-Weaver O, Osmond JM, Riddle MA, Naik JS, Gonzalez Bosc LV, Walker BR \& Kanagy NL 2013 Hydrogen sulfide dilates rat mesenteric arteries by activating endothelial large-conductance $\mathrm{Ca}^{2+}$ activated $\mathrm{K}^{+}$channels and smooth muscle $\mathrm{Ca}^{2+}$ sparks. American Journal of Physiology 304 H1446-H1454 (doi:10.1152/ ajpheart.00506.2012)

Jiang ZG, Nelson CS \& Allen CN 1995 Melatonin activates an outward current and inhibits Ih in rat suprachiasmatic nucleus neurons. Brain Research 687 125-132. (doi:10.1016/0006-8993(95)00478-9) http://jme.endocrinology-journals.org

DOI: 10.1530/JME-17-0028 (c) 2017 Society for Endocrinology Printed in Great Britain
Published by Bioscientifica Ltd 
Ko EA, Han J, Jung ID \& Park WS 2008 Physiological roles of K+ channels in vascular smooth muscle cells. Journal of Smooth Muscle Research 44 65-81. (doi:10.1540/jsmr.44.65)

Ledoux J, Werner ME, Brayden JE \& Nelson MT 2006 Calcium-activated potassium channels and the regulation of vascular tone. Physiology 21 69-78. (doi:10.1152/physiol.00040.2005)

Li M, Tanaka Y, Alioua A, Wu Y, Lu R, Kundu P, Sanchez-Pastor E, Marijic J, Stefani E \& Toro L 2010 Thromboxane A2 receptor and MaxiK-channel intimate interaction supports channel transinhibition independent of G-protein activation. PNAS $\mathbf{1 0 7}$ 19096-19101. (doi:10.1073/pnas.1002685107)

Nelson MT \& Quayle JM 1995 Physiological roles and properties of potassium channels in arterial smooth muscle. American Journal of Physiology 268 C799-C822.

Nichols AJ, Wilson AC \& Hiley CR 1985 Effects of sympathectomy with 6-hydroxydopamine on cardiac output and its distribution in the rat. European Journal of Pharmacology 109 263-268. (doi:10.1016/0014-2999(85)90428-5)

Nosjean O, Ferro M, Coge F, Beauverger P, Henlin JM, Lefoulon F, Fauchere JL, Delagrange P, Canet E \& Boutin JA 2000 Identification of the melatonin binding site MT3 as the quinone reductase 2 . Journal of Biological Chemistry 275 31311-31317. (doi:10.1074/jbc. M005141200)

Pandi-Perumal SR, Trakht I, Srinivasan V, Spence DW, Maestroni GJ, Zisapel N \& Cardinali DP 2008 Physiological effects of melatonin: role of melatonin receptors and signal transduction pathways. Progress in Neurobiology 85 335-353. (doi:10.1016/j.pneurobio.2008.04.001)

Pandi-Perumal SR, BaHammam AS, Ojike NI, Akinseye OA, Kendzerska T, Buttoo K, Dhandapany PS, Brown GM \& Cardinali DP 2016 Melatonin and human cardiovascular disease. Journal of Cardiovascular Pharmacology and Therapeutics (doi:10.1177/1074248416660622)

Paulis L \& Simko F 2007 Blood pressure modulation and cardiovascular protection by melatonin: Potential mechanisms behind. Physiological Research 56 671-684.

Régrigny O, Delagrange P, Scalbert E, Lartaud-Idjouadiene I, Atkinson J \& Chillon JM 1999 Effects of melatonin on rat pial arteriolar diameter in vivo. British Journal of Pharmacology 127 1666-1670. (doi:10.1038/sj.bjp.0702714)

Reiter RJ, Tan DX \& Korkmaz A 2009 The circadian melatonin rhythm and its modulation: possible impact on hypertension. Journal of Hypertension 27 (Suppl 6) S17-S20. (doi:10.1097/01.hjh.0000358832.41181.bf)

Saarela S \& Reiter RJ 1994 Function of melatonin in thermoregulatory processes. Life Sciences 54 295-311. (doi:10.1016/0024-3205(94)00786-1)

Satake N, Oe H \& Shibata S 1991 Vasorelaxing action of melatonin in rat isolated aorta; possible endothelium dependent relaxation. General Pharmacology 22 1127-1133. (doi:10.1016/0306-3623(91)90589-X)

Shi L, Liu B, Li N, Xue Z \& Liu X 2013 Aerobic exercise increases BKCa channel contribution to regulation of mesenteric arterial tone by up regulating $\beta 1$-Subunit. Experimental Physiology 98 326-336 (doi:10.1113/expphysiol.2012.066225)

Shi L, Zhang H, Chen Y, Liu Y, Lu N, Zhao T \& Zhang L 2015 Chronic exercise normalizes changes of Cav1.2 and KCa1.1 channels in mesenteric arteries from spontaneously hypertensive rats. British Journal of Pharmacology 172 1846-1858. (doi:10.1111/bph.13035)

Simonneaux V \& Ribelayga C 2003 Generation of the melatonin endocrine message in mammals: a review of the complex regulation of melatonin synthesis by norepinephrine, peptides, and other pineal transmitters. Pharmacological Reviews 55 325-395. (doi:10.1124/pr.55.2.2)

Steffens F, Zhou XB, Sausbier U, Sailer C, Motemlek K, Ruth P, Olcese J, Korth M \& Wieland T 2003 Melatonin receptor signaling in pregnant and nonpregnant rat uterine myocytes as probed by large conductance Ca2+-activated $\mathrm{K}+$ channel activity. Molecular Endocrinology 17 2103-2115. (doi:10.1210/me.2003-0047)

Sun H, Gusdon AM \& Qu S 2016 Effects of melatonin on cardiovascular diseases: progress in the past year. Current Opinion in Lipidology 27 408-413. (doi:10.1097/MOL.0000000000000314)

Tang ST, Su H, Zhang Q, Tang HQ, Wang CJ, Zhou Q, Wei W, Zhu HQ \& Wang Y 2016 Melatonin attenuates aortic endothelial permeability and arteriosclerosis in streptozotocin-induced diabetic rats: possible role of MLCK- and MLCP-dependent MLC phosphorylation. Journal of Cardiovascular Pharmacology and Therapeutics 21 82-92. (doi:10.1177/1074248415583090)

Thakor AS, Herrera EA, Serón-Ferré MS \& Giussani DA 2010 Melatonin and vitamin $C$ increase umbilical blood flow via nitric oxidedependent mechanisms. Journal of Pineal Research 49 399-406. (doi:10.1111/j.1600-079X.2010.00813.x)

Ting KN, Dunn WR, Davies DJ, Sugden D, Delagrange P, GuardiolaLemaître B, Scalbert E \& Wilson VG 1997 Studies on the vasoconstrictor action of melatonin and putative melatonin receptor ligands in the tail artery of juvenile Wistar rats. British Journal of Pharmacology 122 1299-1306. (doi:10.1038/sj.bjp.0701511)

Tordjman S, Chokron S, Delorme R, Charrier A, Bellissant E, Jaafari N \& Fougerou C 2017 Melatonin: pharmacology, functions and therapeutic benefits. Current Neuropharmacology 15 434-443. (doi:10.2174/1570159X14666161228122115)

Tunstall RR, Shukla P, Grazul-Bilska A, Sun C \& O’Rourke ST 2011 MT2 receptors mediate the inhibitory effects of melatonin on Nitric Oxide-induced relaxation of porcine isolated coronary arteries. Journal of Pharmacology and Experimental Therapeutics 336 127-133. (doi:10.1124/jpet.110.174482)

Viswanathan M, Scalbert E, Delagrange P, Guardiola-Lemaître B \& Saavedra JM 1997 Melatonin receptors mediate contraction of a rat cerebral artery. Neuroreport 8 3847-3849. (doi:10.1097/00001756199712220-00002)

Weekley LB 1991 Melatonin-induced relaxation of rat aorta: interaction with adrenergic agonists. Journal of Pineal Research 11 28-34. (doi:10.1111/j.1600-079X.1991.tb00823.x)

Weekley LB 1993 Effects of melatonin on pulmonary and coronary vessels are exerted through perivascular nerves. Clinical Autonomic Research 3 45-47. (doi:10.1007/BF01819143)

Yang Q, Scalbert E, Delagrange P, Vanhoutte PM \& O'Rourke ST 2001 Melatonin potentiates contractile responses to serotonin in isolated porcine coronary arteries. American Journal of Physiology: Heart and Circulatory Physiology 280 H76-H82.

Yu H, Dickson EJ, Jung SR, Koh DS \& Hille B 2016 High membrane permeability for melatonin. Journal of General Physiology 147 63-76. (doi:10.1085/jgp.201511526)

Zlotos DP, Jockers R, Cecon E, Rivara S \& Witt-Enderby PA 2014 MT1 and MT2 melatonin receptors: ligands, models, oligomers, and therapeutic potential. Journal of Medicinal Chemistry 57 3161-3185. (doi:10.1021/jm401343c)

Received in final form 7 June 2017

Accepted 3 July 2017

Accepted Preprint published online 4 July 2017 http://jme.endocrinology-journals.org

DOI: 10.1530/JME-17-0028
() 2017 Society for Endocrinology Printed in Great Britain
Published by Bioscientifica Ltd 